\title{
20th century trends and budget implications of chloroform and related tri-and dihalomethanes inferred from firn air
}

\author{
D. R. Worton ${ }^{1}$, W. T. Sturges ${ }^{1}$, J. Schwander ${ }^{2}$, R. Mulvaney ${ }^{3}$, J.-M. Barnola ${ }^{4}$, and J. Chappellaz ${ }^{4}$ \\ ${ }^{1}$ School of Environmental Sciences, University of East Anglia, Norwich, UK \\ ${ }^{2}$ Physics Institute, University of Berne, Berne, Switzerland \\ ${ }^{3}$ British Antarctic Survey, Natural Environment Research Council, Cambridge, UK \\ ${ }^{4}$ CNRS Laboratoire de Glaciologie et Geophysique de l'Environnement, Saint Martin d'Heres, France
}

Received: 15 November 2005 - Published in Atmos. Chem. Phys. Discuss.: 24 January 2006

Revised: 11 May 2006 - Accepted: 31 May 2006 - Published: 12 July 2006

\begin{abstract}
Four trihalomethane (THM; $\mathrm{CHCl}_{3}, \mathrm{CHBrCl}_{2}$, $\mathrm{CHBr}_{2} \mathrm{Cl}$ and $\mathrm{CHBr}_{3}$ ) and two dihalomethane (DHM; $\mathrm{CH}_{2} \mathrm{BrCl}$ and $\mathrm{CH}_{2} \mathrm{Br}_{2}$ ) trace gases have been measured in air extracted from polar firn collected at the North Greenland Icecore Project (NGRIP) site. $\mathrm{CHCl}_{3}$ was also measured in firn air from Devon Island (DI), Canada, Dronning Maud Land (DML), Antarctica and Dome Concordia (Dome C), Antarctica. All of these species are believed to be almost entirely of natural origin except for $\mathrm{CHCl}_{3}$ where anthropogenic sources have been reported to contribute $\sim 10 \%$ to the global burden. A 2-D atmospheric model was run for $\mathrm{CHCl}_{3}$ using reported emission estimates to produce historical atmospheric trends at the firn sites, which were then input into a firn diffusion model to produce concentration depth profiles that were compared against the measurements. The anthropogenic emissions were modified in order to give the best model fit to the firn data at NGRIP, Dome C and DML. As a result, the contribution of $\mathrm{CHCl}_{3}$ from anthropogenic sources, mainly from pulp and paper manufacture, to the total chloroform budget appears to have been considerably underestimated and was likely to have been close to $\sim 50 \%$ at the maximum in atmospheric $\mathrm{CHCl}_{3}$ concentrations around 1990 , declining to $\sim 29 \%$ at the beginning of the 21 st century. We also show that the atmospheric burden of the brominated THM's in the Northern Hemisphere have increased over the 20th century while $\mathrm{CH}_{2} \mathrm{Br}_{2}$ has remained constant over time implying that it is entirely of natural origin.
\end{abstract}

\section{Introduction}

Halogens play an important role in the chemistry of both the troposphere and the stratosphere. In the polar troposphere, bromine chemistry has been implicated as the major cause

Correspondence to: D. R. Worton

(d.worton@uea.ac.uk) of surface polar ozone depletion (Barrie et al., 1988; Berg et al., 1984; Cicerone et al., 1988) and bromine monoxide $(\mathrm{BrO})$ as the major atmospheric oxidant driving mercury deposition (Ariya et al., 2004; Ebinghaus et al., 2002; Lindberg et al., 2002; Schroeder et al., 1998). The bromine resulting from the degradation of short lived bromocarbons has been implicated as a possible initiator for the autocatalytic activation and recycling of inorganic halogens from sea salt aerosols causing the observed "bromine explosion" events (Foster et al., 2001; Platt and Honninger, 2003; Sander et al., 2003; Vogt et al., 1999). It has been suggested that $\mathrm{BrO}$ may not be constrained to polar regions but could be widespread throughout the troposphere where it could influence the $\mathrm{HO}_{x}$ and $\mathrm{NO}_{x}$ cycles as well as providing a significant sink for dimethyl sulphide (von Glasow et al., 2004).

In the stratosphere, bromine can deplete ozone with higher efficiency than chlorine, $\sim 45$ times (Daniel et al., 1999), and the dominant sources are understood to be from the photochemical degradation of methyl bromide $\left(\mathrm{CH}_{3} \mathrm{Br}\right)$ and the long lived halon (bromofluorocarbon) compounds. However, recently there is increasing evidence to suggest that other short lived bromocarbon species $\left(\mathrm{CHBr}_{3}, \mathrm{CH}_{2} \mathrm{Br}_{2}\right.$, $\mathrm{CH}_{2} \mathrm{BrCl}, \mathrm{CHBr}_{2} \mathrm{Cl}, \mathrm{CHBrCl}_{2}, \mathrm{C}_{2} \mathrm{H}_{5} \mathrm{Br}$ and $\mathrm{C}_{2} \mathrm{H}_{4} \mathrm{Br}_{2}$ ) could be important source gases of stratospheric bromine. Simultaneous observations of several of these bromocarbons and $\mathrm{BrO}$ in the upper troposphere have been reported (Pfeilsticker et al., 2000), along with several aircraft (Schauffler et al., 1999; Schauffler et al., 1998; Schauffler et al., 1993) and balloon (Kourtidis et al., 1996; Pfeilsticker et al., 2000; Sturges et al., 2000) studies that have shown that these bromocarbons are present at concentrations in the part per trillion by volume (pptv) range and together are reported to contribute $\sim 10-15 \%$ to the total organic bromine measured in the upper troposphere lower stratosphere (UTLS) region (Pfeilsticker et al., 2000; Sturges et al., 2000). It has further been suggested that a fraction of the inorganic bromine originating from the tropospheric breakdown of the same short

Published by Copernicus GmbH on behalf of the European Geosciences Union. 
lived precursors can reach the stratosphere at concentrations that can affect ozone levels (Dvortsov et al., 1999; Nielsen and Douglass, 2001; Pfeilsticker et al., 2000; Salawitch et al., 2005).

Chloroform $\left(\mathrm{CHCl}_{3}\right)$ is the second most abundant organic source of natural chlorine to the atmosphere after methyl chloride and is an important source of tropospheric chlorine. As such it has been one of the subjects of the Reactive Chlorine Emissions Inventory (RCEI). $\mathrm{CHCl}_{3}$ is only estimated to contribute $\sim 2 \mathrm{Gg} \mathrm{CHCl}_{3} / \mathrm{yr}$ or $<10$ pptv (Keene et al., 1999; McCulloch, 2003) to stratospheric chlorine as a result of its short tropospheric lifetime of 0.41 years (Ko et al., 2003) relative to other more persistent chlorine containing source gases. $\mathrm{CHCl}_{3}$ is degraded in the troposphere, through oxidation by $\mathrm{OH}$, to phosgene $\left(\mathrm{COCl}_{2}\right)$ a small percentage of which reaches the stratosphere where it can participate in ozone destruction (Kindler et al., 1995). Chlorine radicals derived from the atmospheric degradation of $\mathrm{CHCl}_{3}$ can react with other organic gases, e.g., hydrocarbons and alkyl nitrates, in the troposphere similar to the $\mathrm{OH}$ radical. This can affect the tropospheric lifetimes of these species as well as influencing the local atmospheric composition, especially in the polar regions. In the case of hydrocarbons and alkyl nitrates the rates of reaction with chlorine radicals are greatly enhanced over those of OH oxidation (IUPAC, 2002; Muthuramu et al., 1994 and references therein).

The global tropospheric bromine loading has been reported to have peaked in 1998 and to have since declined by approximately $5 \%$ or $\sim 0.8$ ppt (Montzka et al., 2003). However, this decrease is reportedly driven by the reduction in atmospheric methyl bromide and the contributions of the very short lived bromocarbons are considered to have remained constant (Montzka et al., 2003) as they are generally assumed to be almost entirely of natural origin.

Recently, Sturges et al. (2001) found no evidence for any significant temporal trends in the Southern Hemisphere concentrations of these bromocarbon gases. There are currently no published Northern Hemisphere trends of brominated trace gases as previous firn air studies of these species and $\mathrm{CH}_{3} \mathrm{Br}$ at Devon Island, Canada (Sturges et al., 2001) and $\mathrm{CH}_{3} \mathrm{Br}$ at Tunu, Greenland (Butler et al., 1999) resulted in the observation of anomalous profiles within the firn that were interpreted as having been affected by post depositional processes.

In this work we present the first unperturbed firn profiles of four trihalomethanes $\left(\mathrm{CHBr}_{3}, \mathrm{CHBr}_{2} \mathrm{Cl}, \mathrm{CHBrCl}_{2}\right.$ and $\mathrm{CHCl}_{3}$ ) for the Northern Hemisphere from firn air collected at North GReenland Icecore Project (NGRIP), Greenland. The anthropogenic contribution to the $\mathrm{CHCl}_{3}$ budget is assessed using a 2-D model and constrained using firn air measurements from Arctic (NGRIP) and Antarctic (Dome Concordia and Dronning Maud Land) sites. The implications for the budgets of the other THM's are also considered based on the observed variations in the NGRIP firn air.

\section{Sampling and analysis}

\subsection{Firn air measurements}

Firn air samples were collected at the North Greenland Icecore Project (NGRIP), Greenland $\left(75^{\circ} \mathrm{N}, 42^{\circ} \mathrm{W}\right)$, Devon Island (DI), Canada $\left(75^{\circ} \mathrm{N}, 82^{\circ} \mathrm{W}\right)$, Dronning Maud Land (DML), Antarctica $\left(77^{\circ} \mathrm{S}, 10^{\circ} \mathrm{W}\right)$ and Dome Concordia (Dome C), Antarctica $\left(75^{\circ} \mathrm{S}, 123^{\circ} \mathrm{E}\right)$ sites. Details of the NGRIP (Reeves et al., 2005) Devon Island, Dome C and DML sites (Sturges et al., 2001), sampling procedures (Schwander et al., 1993; Sturges et al., 2001) and analytical methodologies (Fraser et al., 1999; Oram et al., 1995; Sturges et al., 2001) have been given elsewhere.

In brief, aliquots of the firn air samples $(\sim 400 \mathrm{ml})$ were cryogenically concentrated using liquid argon, then desorbed and separated on a DB- 5 capillary column $(\mathrm{J} \& \mathrm{~W}, 60 \mathrm{~m})$ prior to detection by single ion mode mass spectrometry (Micromass Autospec) with detection limits of $\sim 0.001 \mathrm{pptv}$. The associated experimental uncertainties, as illustrated by the error bars in subsequent figures, were determined as the total analytical precision through duplicate analyses of samples at each depth and the measurement precision of the running standard. $\mathrm{CHCl}_{3}$ measurements are presented from all four firn sites whereas the brominated tri- and dihalomethanes are only presented for the NGRIP site. The brominated species have also been measured at the other three sites and were reported previously by Sturges et al. (2001).

\subsection{Firn modelling}

A firn physical transport model that accounts for gravitational fractionation and gaseous diffusion (Rommelaere et al., 1997) was employed to interpolate atmospheric trends into firn concentration depth profiles. The required tortuosity profile was determined by inverse modelling of the $\mathrm{CO}_{2}$ profile (Fabre et al., 2000). Diffusion coefficients of other molecules relative to $\mathrm{CO}_{2}$ were estimated from Le Bas molecular volumes (Fuller et al., 1966). Thermal fractionation effects were not included in the model.

\subsection{Atmospheric model}

Temporal trends in atmospheric concentrations for the locations of the firn sites were generated using a 2-D atmospheric chemistry transport model. Details of the model are given in Reeves (2003). The model contains 18 equal area latitudinal bands and 6 vertical layers, each of $2.5 \mathrm{~km}$. The ocean component of the 2-D model was removed as the lifetime of $\mathrm{CHCl}_{3}$ with respect to loss to the ocean has been reported to be insignificant (Kindler et al., 1995; Yvon-Lewis and Butler, 2002) relative to the $\sim 0.41$ year lifetime resulting from the reaction with $\mathrm{OH}$ (Ko et al., 2003). Other sink terms including dry deposition and loss to soils were also removed as the reaction with $\mathrm{OH}$ was considered to be the dominant loss 
process (Keene et al., 1999; McCulloch, 2003). The stratospheric lifetime of $\mathrm{CHCl}_{3}$ has been estimated at 3.18 years (Kindler et al., 1995) and this was used to determine the diffusive loss term out of the uppermost layer of the model.

\section{Results and discussion}

\subsection{Firn depth profiles}

\subsection{1 $\mathrm{CHCl}_{3}$}

Figure 1 shows the $\mathrm{CHCl}_{3}$ measurements at four polar sites (NGRIP, DI, Dome C and DML) plotted versus CFC-12 instead of depth. This is in order to give an axis that is more linear with time and that allows comparisons between different sites (Sturges et al., 2001) because CFC-12 is long lived and has increased in both hemispheres at the same rate. The samples collected in the convective zones (i.e., effectively surface air) are not included in the comparison plots (above $10 \mathrm{~m}$ for NGRIP and Dome C, and above 3 and $5 \mathrm{~m}$ for DI and DML, respectively). There is excellent agreement between the two arctic sites (NGRIP and DI) and between the two Antarctic sites (DML and Dome C). Fig. 1 would suggest that in the Northern Hemisphere the atmospheric concentration of $\mathrm{CHCl}_{3}$ has increased by almost a factor of 2, from 7 to $14 \mathrm{pptv}$, before declining in more recent times to around 10 pptv. $\mathrm{CHCl}_{3}$ in the Southern Hemisphere would also appear to have increased but not to the same degree with an increase of $\sim 2 \mathrm{pptv}$. The maximum $\mathrm{CHCl}_{3}$ concentrations occur at the $66.99 \mathrm{~m}$ sample depth, which as will be shown later (Sect. 3.2) corresponds to a date of $\sim 1990$.

The major sink for atmospheric chloroform is from the reaction with $\mathrm{OH}$ (Keene et al., 1999; McCulloch, 2003) and the global average concentration of these radicals has been reported to have increased by $\sim 15 \pm 22 \%$ between 1979 and 1989 and to subsequently have decreased to levels in 2000 that were $\sim 10 \pm 24 \%$ lower than those in 1979 (Prinn et al., 2001). These findings are disputed due to reported continued emissions of methyl chloroform, used to determine the $\mathrm{OH}$ trend, from Europe that call into question the magnitude of the initial $\mathrm{OH}$ increase and the existence of a negative trend during the 1990's (Krol et al., 2003). These variations even if they are correct are not only unlikely to be significant enough to explain the magnitude of the observed variations but they are also in anti-phase to the observed changes in the $\mathrm{CHCl}_{3}$ concentrations such that variations from $\mathrm{OH}$ driven changes in the atmospheric lifetime cannot be responsible. It is also unlikely that the observed variations recorded in the firn are due to changes in the natural fluxes from the oceans and soils as a result of the relatively short timescales involved. Although, the perturbation of the natural source fluxes by anthropogenic activities cannot be discounted, e.g., variations in soil based emissions as a result of changing agri-

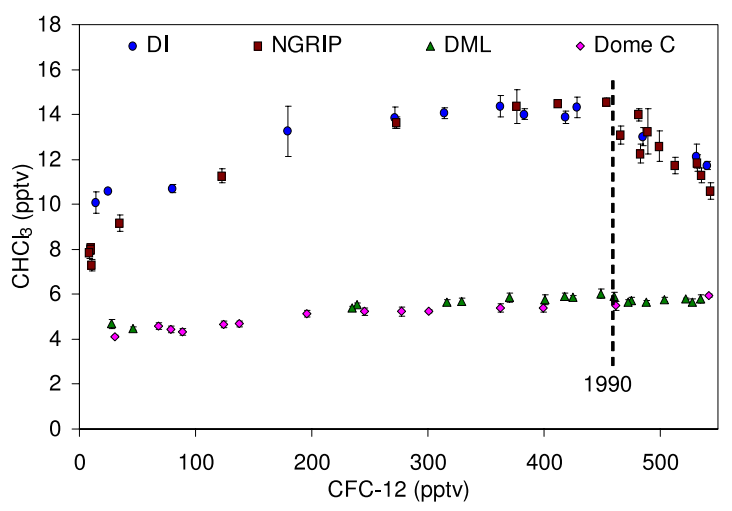

Fig. 1. Firn air measurements of $\mathrm{CHCl}_{3}$ versus $\mathrm{CFC}-12$ at NGRIP and DI in the Arctic and DML and Dome $\mathrm{C}$ in the Antarctic.

cultural practices or increased oceanic emissions resulting from human forced climatic changes.

\subsubsection{Bromocarbons}

Figure 2 shows the measured concentration depth profiles of $\mathrm{CHBr}_{3}, \mathrm{CHBr}_{2} \mathrm{Cl}, \mathrm{CHBrCl}_{2}, \mathrm{CH}_{2} \mathrm{BrCl}$ and $\mathrm{CH}_{2} \mathrm{Br}_{2}$ derived from NGRIP firn air. The lines represent the firn model outputs corresponding to constant atmospheric burdens over time (the scenarios in all cases begin in 1900). As a result of their OH and photolysis sinks (Ko et al., 2003) the concentrations in the shallow firn reflect the seasonal variations in atmospheric concentrations (Kaspers et al., 2004; Sturges et al., 2001). Essentially, the summer firn drilling takes place when $\mathrm{OH}$ and photolysis levels are close to the peak annual values and as a result the concentrations of these halocarbons species are at a minimum. The gradients between the surface and $15 \mathrm{~m}$ reflect the atmospheric concentrations from the previous 6 months or so and as such show the variation between the winter and summer concentrations. The scatter in the ambient $(0 \mathrm{~m})$ measurements is the result of variations in the local meteorological conditions between sample collections.

The modelled lines shown in Fig. 2 incorporate seasonal cycles for $\mathrm{CHBr}_{3}$ and $\mathrm{CHBr}_{2} \mathrm{Cl}$, based on measurements from Alert, Canada (Yokouchi et al., 1996) and for $\mathrm{CH}_{2} \mathrm{Br}_{2}$ from measurements at Alert, Canada and Point Barrow, Alaska (Montzka, 2005). As no seasonality for $\mathrm{CHBrCl}_{2}$ in the polar regions was available in the literature the same seasonality as for $\mathrm{CHBr}_{2} \mathrm{Cl}$ was assumed based on similarities in their lifetimes, 77 and 69 days respectively, (Ko et al., 2003). Yokouchi et al. (1996) reported no seasonal variation for $\mathrm{CH}_{2} \mathrm{BrCl}$ at Alert and the NGRIP firn measurements show very little evidence for a seasonal cycle, most likely reflecting its longer atmospheric lifetime (Ko et al., 2003). It appears from these firn profiles that the annual mean atmospheric concentration of the $\mathrm{CH}_{2} \mathrm{Br}_{2}$ and $\mathrm{CH}_{2} \mathrm{BrCl}$ have been constant implying that non-natural sources are insignificant, although for $\mathrm{CH}_{2} \mathrm{BrCl}$ the interpretation is complicated in the deepest firn by high concentrations that could be the 

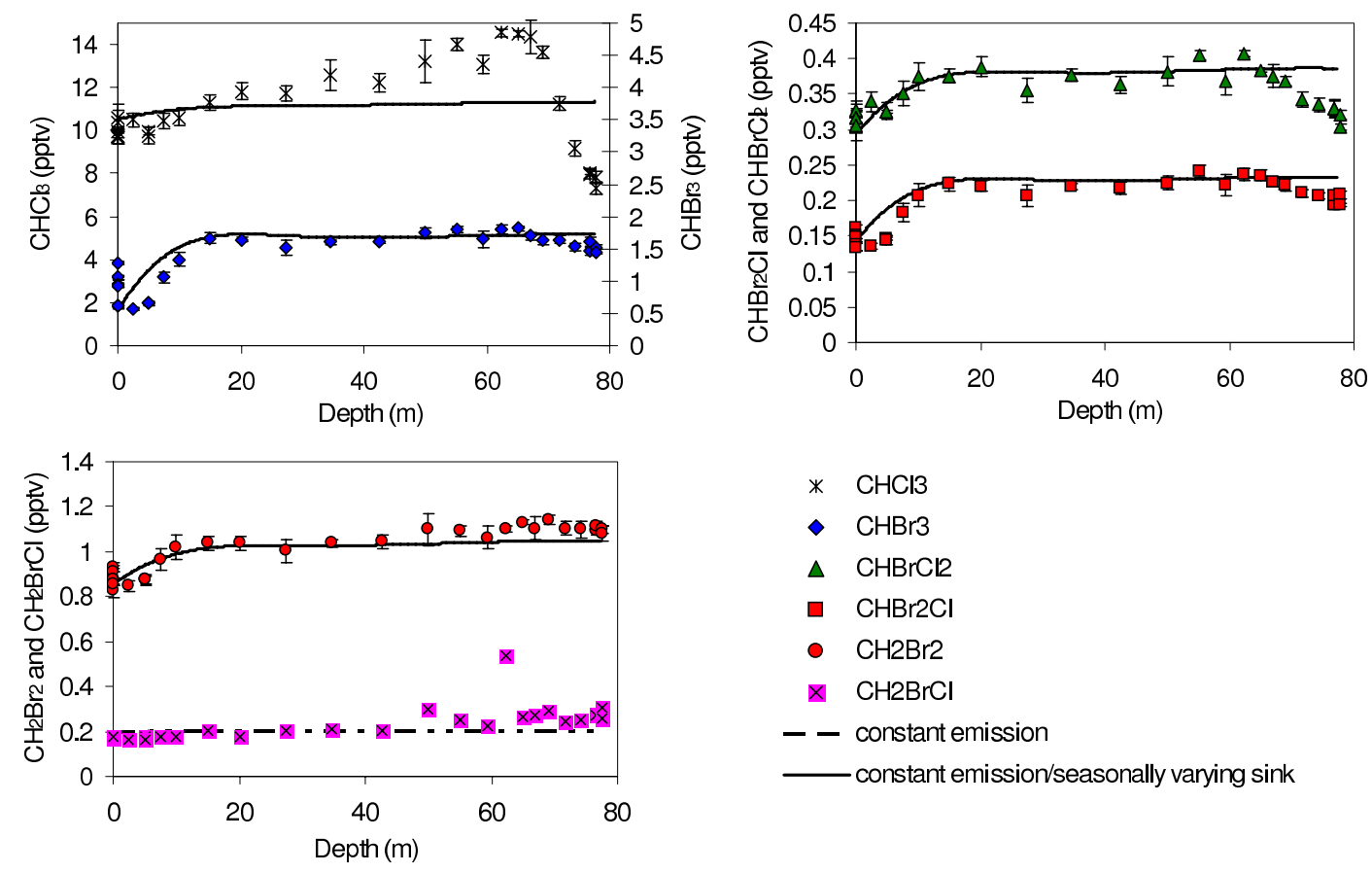

Fig. 2. Depth profiles of the THM and DHM in firn air from NGRIP (symbols). Model lines corresponding to constant atmospheric burdens incorporating seasonal cycles, where appropriate, are also shown.

result of post deposition effects. In contrast, it is evident that an increase in the atmospheric concentrations of $\mathrm{CHBr}_{3}$, $\mathrm{CHBr}_{2} \mathrm{Cl}$ and $\mathrm{CHBrCl}_{2}$ are necessary in order to explain the observed behaviour in the deepest firn. The similar nature of the observed changes in the deepest firn would implicate a similar source driving the increases in the brominated THM concentrations. The large magnitude change in the $\mathrm{CHCl}_{3}$ concentrations at NGRIP (Fig. 2) relative to the brominated THM's implies a different source is likely to be responsible for the observed variations in atmospheric $\mathrm{CHCl}_{3}$.

Figure 3 shows the measurements of $\mathrm{CHBr}_{3}, \mathrm{CHBr}_{2} \mathrm{Cl}$ and $\mathrm{CHBrCl}_{2}$ versus CFC-12 at NGRIP. As a result of the seasonally influenced concentrations the samples collected in the shallow firn $(<30 \mathrm{~m})$ are not included in this plot and the remaining data have been corrected for the effects of gravitational settling, which causes heavy molecules to be enriched at depth in the firn column relative to lighter ones. The depth where the concentrations "level off" can be dated at $\sim 1992$, based on the dates determined through the atmospheric $\mathrm{CHCl}_{3}$ modelling (Sect. 3.2). It is important to note that the diffusion coefficients and hence the diffusion rates for the various trace gases within the firn are distinct such that the inferred age scale is only approximate.

\subsection{Atmospheric modelling}

The global $\mathrm{CHCl}_{3}$ emissions were separated into 5 major source terms; oceans, soils, pulp and paper $(\mathrm{P}+\mathrm{P})$, water chlorination (WC) and other industrial processes (OI).
Biomass burning is only considered to be a very minor component, $<2 \mathrm{Gg} \mathrm{CHCl}_{3} / \mathrm{yr}$ or $<1 \%$ of the total annual emissions (Lobert et al., 1999), relative to the other natural emissions and thus was not included.

\subsubsection{Natural emissions and distributions}

Natural emissions are reported to be significantly larger than anthropogenic releases but are also far less constrained (Keene et al., 1999; McCulloch, 2003). The absolute values for both ocean and soil emissions are based on measurements made by Khalil et al. (1983) and Khalil and Rasmussen (1998) whose calibration scale for $\mathrm{CHCl}_{3}$ has been shown, through an intercomparison of measurements at Cape Meares $\left(45^{\circ} \mathrm{N}, 124^{\circ} \mathrm{W}\right)$ (Khalil and Rasmussen, 1999) and Trindad Head $\left(41^{\circ} \mathrm{N}, 124^{\circ} \mathrm{W}\right)$ (O'Doherty et al., 2001), to over estimate $\mathrm{CHCl}_{3}$ concentrations by a factor of $\sim 2$ relative to the Atmospheric Lifetime Experiment/Global Atmospheric Gases Experiment/Advanced Global Atmospheric Gases Experiment (ALE/GAGE/AGAGE) network. This factor is also likely to be appropriate for comparisons to measurements made by the National Oceanic and Aeronautical Administration - Climate Monitoring and Diagnostic Laboratory (NOAA-CMDL) flask sampling network, which have been shown to be in good agreement $(<5 \%)$ with the ALE/GAGE/AGAGE measurements (Cox et al., 2003; O'Doherty et al., 2001). Hence, it follows that the quoted emission values are also likely to be overestimates by the same factor such that the values used in this work are $180 \pm 45$ 


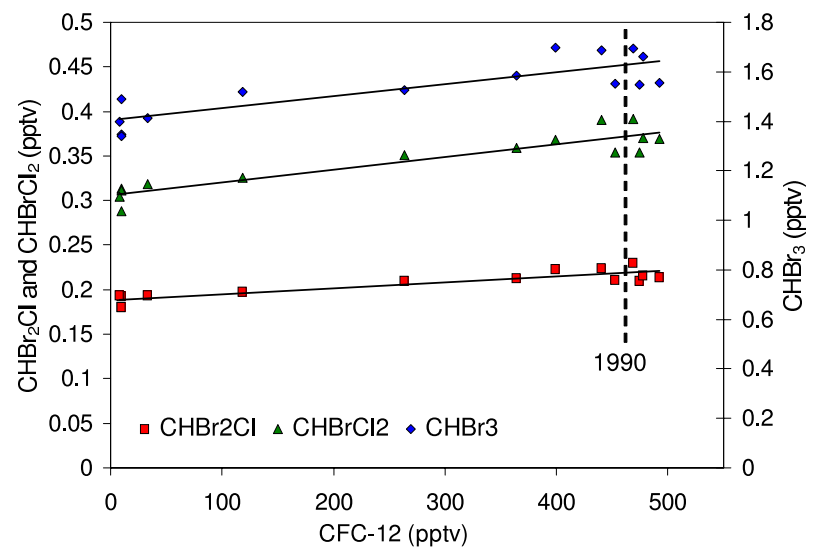

Fig. 3. Gravity corrected firn air measurements of $\mathrm{CHBr}_{3}$, $\mathrm{CHBr}_{2} \mathrm{Cl}$ and $\mathrm{CHBrCl}_{2}$ versus $\mathrm{CFC}-12$ at NGRIP.

and $100+100 /-50 \mathrm{Gg} \mathrm{CHCl}_{3} / \mathrm{yr}$ for oceans and soils, respectively, i.e., $\sim 50 \%$ lower than those values reported by Khalil et al. (1999).

As a result of the significant reported uncertainties in the natural emission magnitudes and a lack of information concerning the likely source distributions, the RCEI did not attempt to estimate the latitudinal distribution. Nevertheless as part of the RCEI's work (Khalil et al., 1999) the ocean and soil emissions were constrained into 4 latitudinal bands; 0 $30^{\circ}, 30-90^{\circ}$ for each hemisphere. In order to incorporate the natural emissions into our model it was necessary to estimate the distribution of the natural sources on a finer scale (i.e., 18 latitudinal boxes). This was achieved by assuming that the flux rates per unit area within these bands are uniformly distributed. The latitudinal distribution of natural emissions from this very simple approach, from now on referred to as ND1, is shown in Fig. 4.

A second approach was aimed at developing this first approximation into a more smoothed distribution. This approach involved determining emission factors for the ocean and soils based on their fractional global coverage Gross (1972), which was used in conjunction with the assumption that the tropical oceans $\left(\leq 30^{\circ}\right)$ are more productive than the sub tropics $\left(>30^{\circ}\right)$ and that this relationship was linear with latitude, i.e., increasing linearly towards the equator. This assumption is supported in essence by the greater emissions reported at lower latitudes by Khalil et al. (1999), although the linearity of the relationship is based on speculation only. For the soils, they were assumed to cover all areas that were not classified as oceans (Gross, 1972) and the emission factor was assumed to be independent of latitude and thus constant for the entire globe. This assumption is clearly limited since there are large differences in soil and landscape types. Soil emissions from the most southerly box were set to zero since the only land mass $<60^{\circ} \mathrm{S}$ is Antarctica. However, due to the resolution of the model, it was not possible to assume the same for the most northerly box because there

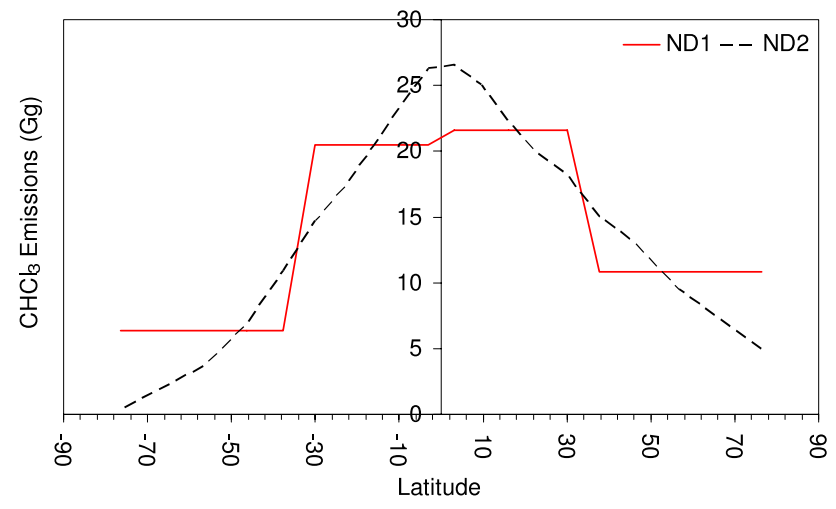

Fig. 4. The two estimated natural distributions (ND1= natural distribution 1, ND2 = natural distribution 2 as defined in Sect. 3.2.1) used within this 2-D modelling work. The $\mathrm{x}$-axis represents the latitude with positive values reflecting the Northern Hemisphere and negative values the Southern Hemisphere.

is not a permanent icesheet covering all land masses $>60^{\circ} \mathrm{N}$.

To obtain a distribution that fitted within the constraints of all these parameters it was necessary to use individual normalisation factors for both the oceans and the soils to correct the calculated figures within each of the 4 larger semi hemispheric bands to match those reported by Khalil et al. (1999). All of these applied normalisation factors were $1.0 \pm 0.1$ giving good confidence for the calculated figures and for comparisons between the individual model boxes. It should be noted that the applied soil emission factors $>33^{\circ} \mathrm{S}$, i.e. in the most southerly semi-hemisphere, are higher by a factor of $\sim 2.6$ than for all other latitudes. This appears to be necessary in order to match the estimated emissions of Khalil et al. (1999) without requiring a large normalisation factor. Since land accounts for only 0.2 to $7.4 \%$ of the surface area in these boxes, this has a negligible effect on the overall budget. This distribution, from now referred to as ND2, is shown in Fig. 4.

\subsubsection{Anthropogenic distributions and trends}

In the literature, the estimated anthropogenic source strengths of $\mathrm{CHCl}_{3}$ are reportedly small (Aucott et al., 1999) relative to the estimated natural emissions (Khalil et al., 1999). The associated uncertainties reported (Aucott et al., 1999; Khalil et al., 1999) with these estimates would suggest that the anthropogenic source strength is better constrained and hence more well known although this work, as will be shown, would suggest that this is unlikely to be correct. As part of the RCEI work a global $1^{\circ} \times 1^{\circ}$ grided inventory of anthropogenic $\mathrm{CHCl}_{3}$ emissions was produced based on 1990 estimates (Aucott et al., 1999). The $3 \mathrm{Gg} \mathrm{CHCl}_{3} / \mathrm{yr}$ emissions resulting from combustion sources, landfills and ruminants were not included in the grided inventory as they were considered to be too small to make a significant impact (Aucott et al., 1999). As emissions were given as mass 


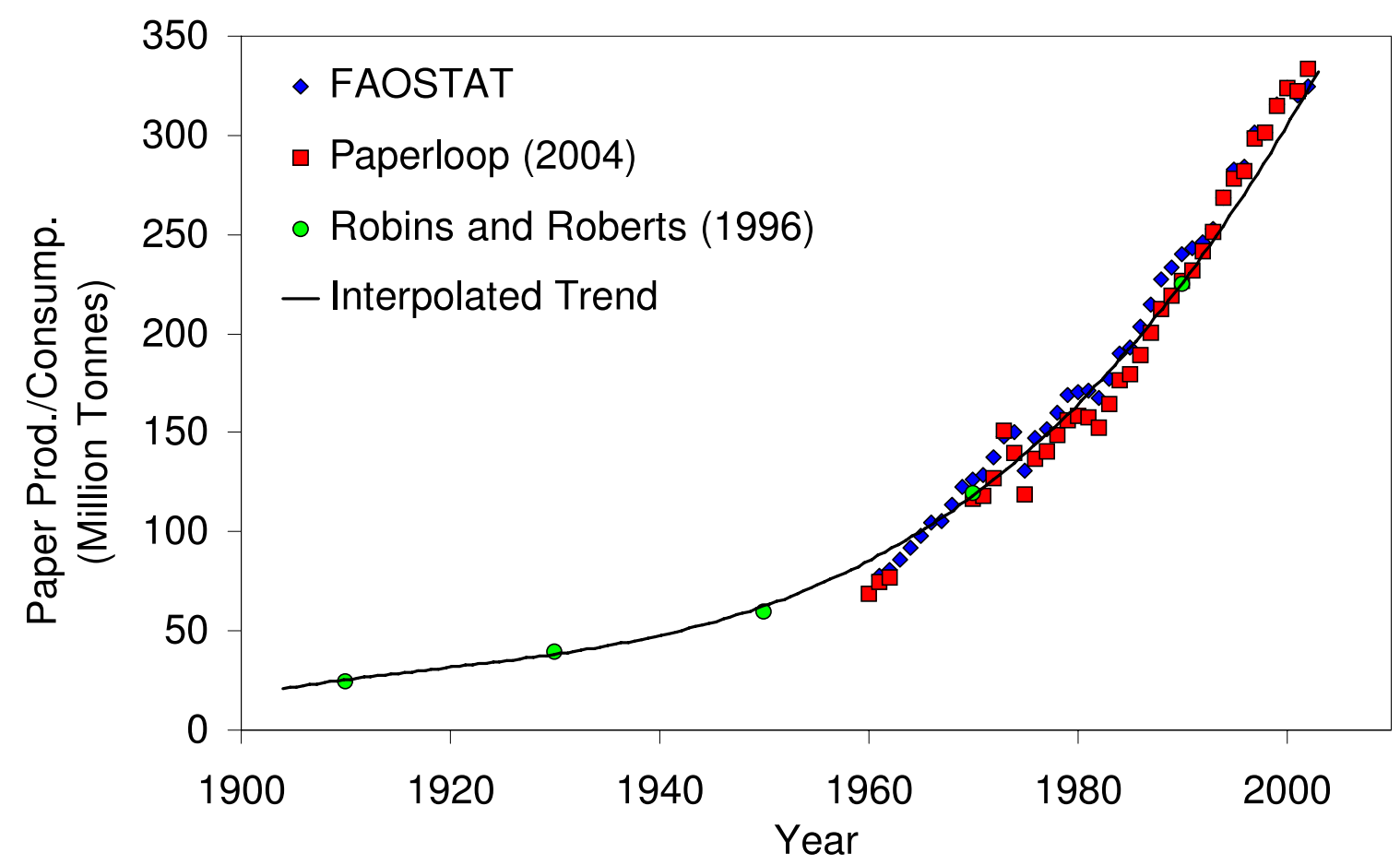

Fig. 5. The reported global trend in paper production/consumption during the 20th century and the interpolated trend used to construct a time history of the pulp and paper industry (FAOSTAT = food and agricultural organisation of the United Nations online statistics service).

emission per square metre it was necessary to multiply by the prescribed grid cell areas. These grid cell emissions were averaged into the latitudinal bands of the 2-D model to give a latitudinally dependent source distribution. The grided inventory suggests that $\sim 93 \%$ of anthropogenic emissions are emitted in the Northern Hemisphere.

In 1990, $51 \%$ of the grided anthropogenic emissions ( $34 \mathrm{Gg} \mathrm{CHCl}_{3} / \mathrm{yr}$ ) were estimated to originate from the manufacture of pulp and paper, $32 \%$ from the chlorination of drinking waters and the chlorination of cooling waters used in power plants $\left(21 \mathrm{Gg} \mathrm{CHCl}_{3} / \mathrm{yr}\right)$ and $17 \%$ from other industrial uses (11 Gg $\mathrm{CHCl}_{3} / \mathrm{yr}$ ) (Aucott et al., 1999).

\subsubsection{Anthropogenic trends}

By assuming that all three anthropogenic source terms have identical global distributions allows us to separate them and consider their temporal evolutions independently. As there are not any long term trends which describe the evolution of these source emissions it was necessary to use surrogates in order to extrapolate their values to the beginning of the 20th century.

In the case of the pulp and paper industry the surrogate chosen was the global trend in paper production and/or consumption (Fig. 5) determined from a 3rd order polynomial fit to reported global figures for the period 1910-2002 (FAOSTAT, 2004; Paperloop, 2004; Robins and Roberts, 1996), with the greatest frequency of data occurring post 1960 . The more recent higher frequency datasets of the food and agriculture organisation of the United Nations (FAOSTAT, 2004) and Paperloop (2004) are for paper production, whereas the longer trend of Robins and Roberts (1996) is for paper consumption. There is good overlap between the three datasets, which suggests that the differences between production and consumption are negligible in the interests of this approximation. Now by assuming that in 1990 the amount of paper produced released the reported emissions of $\mathrm{CHCl}_{3}$ facilitates the determination of an emission factor $\left(145 \mathrm{~g} \mathrm{CHCl}_{3}\right.$ / ton of paper) that allows the extrapolation of $\mathrm{CHCl}_{3}$ emissions from the pulp and paper industry as a function of paper production. This emission factor lies within the range of previous estimates (Aucott, 1997 and references therein) and as such is consistent with previous calculations. In 1990, 95\% of the global bleached chemical pulp used molecular chlorine (AET, 2001) and therefore the relationship between $\mathrm{CHCl}_{3}$ emissions and paper production ought to be linear and in the pursuit of simplicity was assumed as such.

This surrogate was used to determine only the pre-1990 trend for the $\mathrm{P}+\mathrm{P}$ industry due to significant changes in the industry during the 1990's (AET, 2001). The changing trends within the global industry are illustrated in Fig. 6, which shows that the percentage of global bleached chemical pulp production using elemental chlorine has decreased by slightly more than a factor of 5 , from $\sim 95 \%$ in 1990 to $\sim 17 \%$ in 2002 , and that the elemental chlorine free (ECF) and totally chlorine free (TCF) bleaching methods have both 


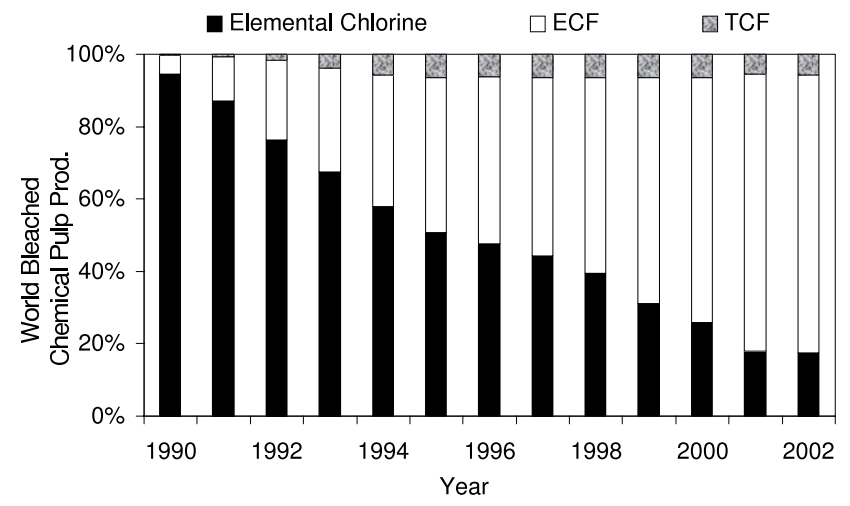

Fig. 6. The changing trend in the bleaching methods; elemental chlorine, elemental chlorine free (ECF) and totally chlorine free (TCF), used in the pulp and paper industry during the 1990's (AET, 2001).

increased over the same time frame, from $5 \%$ to $68 \%$ and $0.2 \%$ to $6.5 \%$, respectively (AET, 2001). These changing trends are reflected, for the United States of America (USA) at least, by significant reductions $(\sim 86 \%)$ in the air emissions of $\mathrm{CHCl}_{3}$ from the $\mathrm{P}+\mathrm{P}$ industry (USEPA, 2004). This declining trend was well approximated $\left(\mathrm{R}^{2}=0.98\right)$ by a 2 nd order polynomial function, which was used in all further calculations. The decline in the USA's use of elemental chlorine in pulp production is shown (Fig. 7) to be well correlated $\left(\mathrm{R}^{2}=+0.74\right)$ with the global decrease (AET, 2001). This correlation suggests that it is reasonable to assume that the observed decrease in $\mathrm{CHCl}_{3}$ emissions from the USA $\mathrm{P}+\mathrm{P}$ industry (USEPA, 2004) also reflects what has been occurring on a global scale. This is a reasonably quantitative assumption since the USA's $\mathrm{P}+\mathrm{P}$ production has accounted for $\geq 30-60 \%$ of world production over the last 40 years (Paperloop, 2004). These approximations were used to determine the declining trend in $\mathrm{CHCl}_{3}$ emissions from the global $\mathrm{P}+\mathrm{P}$ industry for the period 1990-2002 and combined with the surrogate trend based on paper production and consumption figures to give an estimation of the 20th century emission history.

The global population was used as a surrogate for WC and OI processes and was based on the assumption that with an increasing population comes an increasing demand and use of chlorinated drinking water and an increasing demand for electricity and hence a likely increase in the amount of cooling water chlorinated for use in power stations. The increasing global population is also likely to reflect the additional demands of an industrialising society that are considered as part of the other industrial processes by the RCEI. The global population has been used previously as a surrogate for anthropogenic $\mathrm{CHCl}_{3}$ emissions (Trudinger et al., 2004) and this trend was determined from population figures above the 1920 population, hence fixing a timeframe for zero emissions. The chlorination of water began at the turn of

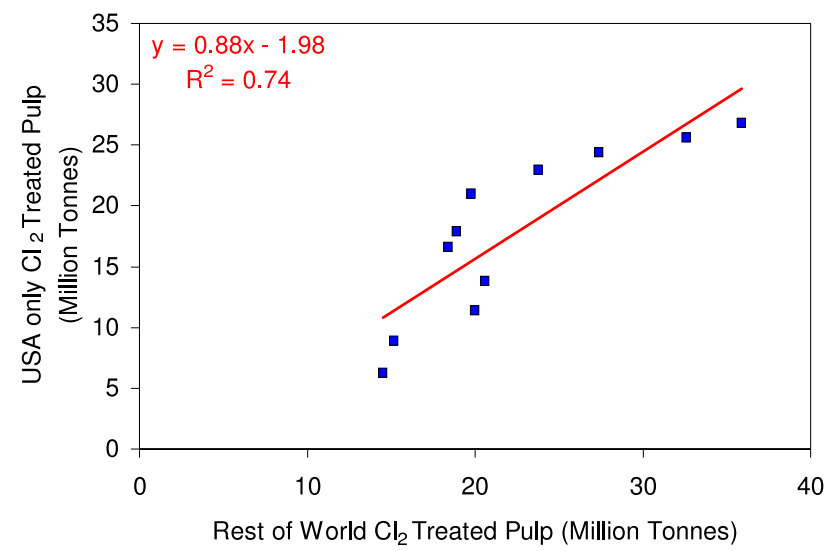

Fig. 7. The relationship between the use of elemental chlorine during the bleaching of paper pulp in the United States of America (USA) and the rest of the world.

the century and became widespread by 1920 (AWWA, 2004) suggesting a reasonable approximation for zero emissions.

The global population trend was determined from data published by the United Nations (UN, 2004) and the Population Reference Bureau (Ashford et al., 2004) with the higher frequency data occurring post 1950 . It was necessary to assume a linear growth rate between 1900 and 1950 due to lack of data. A surrogate global population trend was devised by correcting to population figures above that of 1920 . Now by assuming that in 1990 the reported releases of $\mathrm{CHCl}_{3}$ for the water chlorination and other industrial processes categories were associated with the surrogate population at that time allows the determination of emission factors, 6.28 and $3.34 \mathrm{Gg}$ $\mathrm{CHCl}_{3}$ / billion people for water chlorination and other industrial processes, respectively. These emission factors allow the determination of $\mathrm{CHCl}_{3}$ emissions from these industries as a function of the global population.

The temporal variations, over a 100 year period, for all source terms, including a trend that incorporates a changing soil source (Sect. 3.2.4), are shown in Fig. 8. A critical assumption is that the natural emissions from oceans and soils have not changed over this time frame. We concede that increased emissions from the biosphere could have taken place during the 20th century, e.g., as a result of increasing global temperatures. However, there is scant evidence to support such increases as a result of the apparent lack of increasing trends in the THM and DHM measurements in the Southern Hemisphere (Sturges et al., 2001) and the DHMs in the Northern Hemisphere (this work). The largest changes occur in the Northern Hemisphere and since it is hard to imagine a natural source that only operates in one hemisphere a large variation in the anthropogenic emissions needs to be invoked to describe the observations. An inherent assumption with this approach is that the latitudinal distribution of all source terms has remained constant over time. 


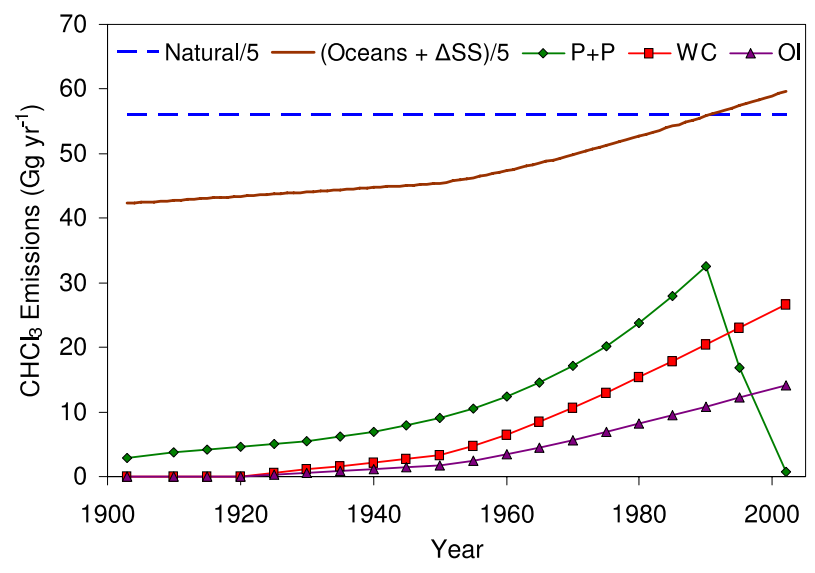

Fig. 8. The time trends over the 20th century for all the natural and anthropogenic source components $(\triangle \mathrm{SS}=$ changing soil source; $\mathrm{P}+\mathrm{P}=$ pulp and paper; $\mathrm{WC}=$ water chlorination; $\mathrm{OI}=$ other industries) incorporated in the modelling.

\subsubsection{Varying the soil source as function of population}

To reconcile their modelling results, Trudinger et al. (2004) hypothesise that the soil source may have increased with time as a result of agricultural interference. This is supported by a recent report that suggests that the amount of land being cultivated has increased substantially in recent times and that since 1940 the amount of land turned over to agriculture was larger than in the two previous centuries combined (UN, 2005). However, the notion that cultivated soil emits more $\mathrm{CHCl}_{3}$ than uncultivated soils is one of speculation and there is no supporting evidence for this at the current time.

To investigate Trudinger et al.'s suggestion of an increasing soil source, the soil emissions were fixed at $100 \mathrm{Gg}$ $\mathrm{CHCl}_{3}$ for 1990 and extrapolated back to the beginning of the century as a function of the global population in the same way as was performed for the WC and OI temporal variations. This trend is referred to from now on as the changing soil source $(\Delta \mathrm{SS})$ and is shown in Fig. 8. The effect of constant soil and changing soil emissions are discussed in Sect. 3.2.5. It is apparent that a much smaller variation in the natural emissions (e.g., soils) would be needed relative to any changes in the anthropogenic emissions to affect the same magnitude change in the concentrations observed at the Antarctic sites, as a result of the northern mid latitude bias of the anthropogenic distribution.

\subsubsection{Varying the magnitude of anthropogenic emissions}

The reported (Aucott 1997) uncertainty levels associated with each of the anthropogenic source terms suggest that the reported values (Aucott et al., 1999) could be up to a factor of 2 larger. Therefore, all the anthropogenic emissions were doubled, which resulted in a better approximation to the NGRIP data (Fig. 9). The changing soil source $(\Delta \mathrm{SS})$

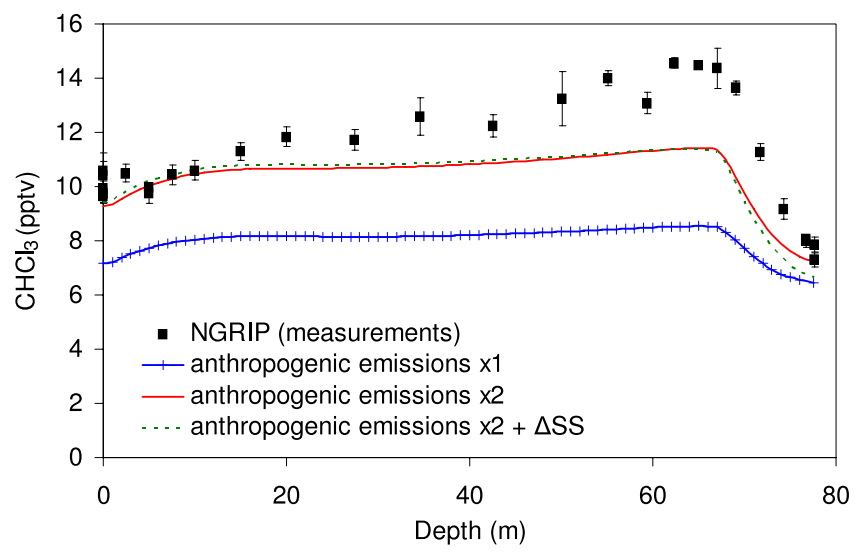

Fig. 9. A comparison of the effect of varying the magnitude of all anthropogenic sources $(\mathrm{x} 1=$ reactive chlorine emissions inventory (RCEI) figures as reported by Aucott et al. (1999); x2=double the reported RCEI figures; $\mathrm{x} 2+\Delta \mathrm{SS}=$ double the RCEI figures plus changing soil source) with the NGRIP firn air measurements of $\mathrm{CHCl}_{3}$.

scenario is also shown in Fig. 9 and the effects observed at NGRIP are reasonably small with slightly lower values being modelled in the deeper part of the profile whilst the opposite is apparent for the near surface. The effect of this scenario is more significant for the Southern Hemisphere sites (not shown) where the higher values in the shallow firn and lower values in the deeper firn appear to improve the fit to the measurements. However, these improved fits are more likely reflecting the consequence of the distribution of soil coverage within the model as opposed to a definitive anthropogenic perturbation.

It is evident from Fig. 9 that the magnitude of the anthropogenic emissions required to fully capture the maximum values observed in the NGRIP firn air measurements still needs to be larger than double the reported values. The strong declining trend in atmospheric $\mathrm{CHCl}_{3}$ observed at NGRIP coupled with the proposed source trends would suggest that only by further increasing the emissions from the $\mathrm{P}+\mathrm{P}$ industry would it be possible to both model the maximum values observed in the firn while still maintaining a good approximation to the observed decline in the firn between $60 \mathrm{~m}$ and the surface. Several runs were performed to evaluate the sensitivity of the model to increases in emissions from the $\mathrm{P}+\mathrm{P}$ industry. During these model runs the natural emissions were constrained at a constant value of $280 \mathrm{Gg} \mathrm{CHCl}_{3}$ yr throughout. The magnitude of the WC and OI emissions were fixed at either the reported values (Aucott et al., 1999) or at double these values dependent on the particular run. The $\mathrm{P}+\mathrm{P}$ emissions were varied between 3-5 times the value reported by Aucott et al. (1999).

The various model outputs are shown in Fig. 10 where it is clear that too effectively model the near surface 


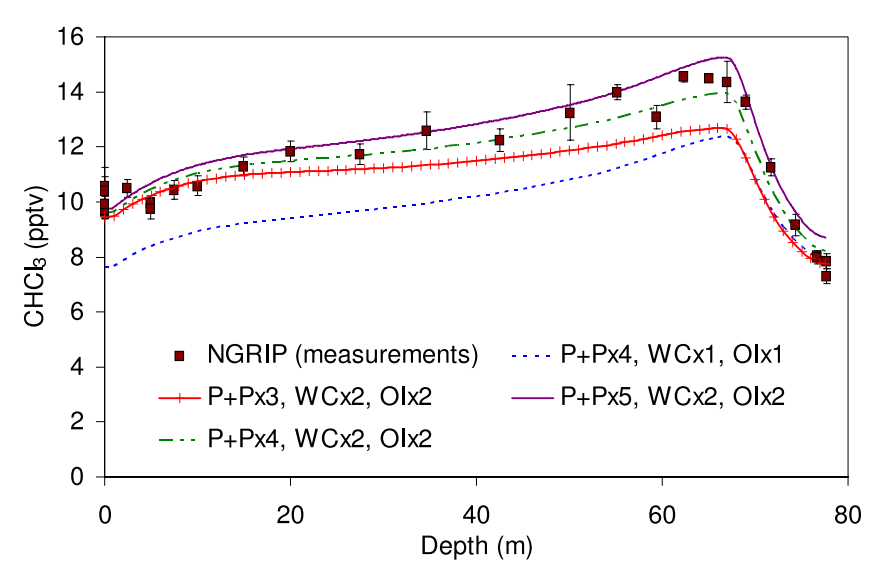

Fig. 10. A comparison of the effect of varying the magnitude of the various independent anthropogenic source components $(\mathrm{P}+\mathrm{P}=$ pulp and paper; $\mathrm{WC}=$ water chlorination; $\mathrm{OI}=$ other industries) relative to the NGRIP firn air measurements of $\mathrm{CHCl}_{3}$.

concentrations the emissions from the $\mathrm{WC}$ and $\mathrm{OI}$ industries need to be double those reported in the literature. $\mathrm{P}+\mathrm{P}$ emissions between $\sim 4-5$ times the reported values would appear to be necessary to simulate the maximum $\mathrm{CHCl}_{3}$ concentrations observed in the firn with the bias being towards the upper end of this range. We are not alone in believing that the anthropogenic emissions fluxes have been underestimated, Trudinger et al. (2004) also invoked an increase in emissions from anthropogenic sources to model their firn air measurements although our magnitude is smaller by comparison. The conclusions regarding the magnitude of the anthropogenic emissions are based on the assumption that the magnitude of the natural emissions are correct. It should be noted that although the uncertainties in the natural source terms are fairly large, the fact that the concentrations observed at the bottom of the firn at NGRIP where natural emissions account for $>90 \%$ of the total emissions coupled with the modelled concentrations for Dome C and DML together suggest that the emission magnitudes are reasonable. The values corresponding to the model outputs corresponding to the increased anthropogenic emissions are shown as latitudinal variations for 1990 levels compared against the natural emissions in order to illustrate the importance of the anthropogenic contribution to the total budget. The largest contribution is in the Northern Hemisphere mid latitudes where this modelling would suggest that the anthropogenic emissions strongly dominant over the natural emissions (Fig. 11).

3.2.6 Latitudinal variation of peak anthropogenic emissions

In order to model the sensitivity of the location of the latitudinal maximum peak in the anthropogenic emissions the peak of the emissions was moved north and south while keeping

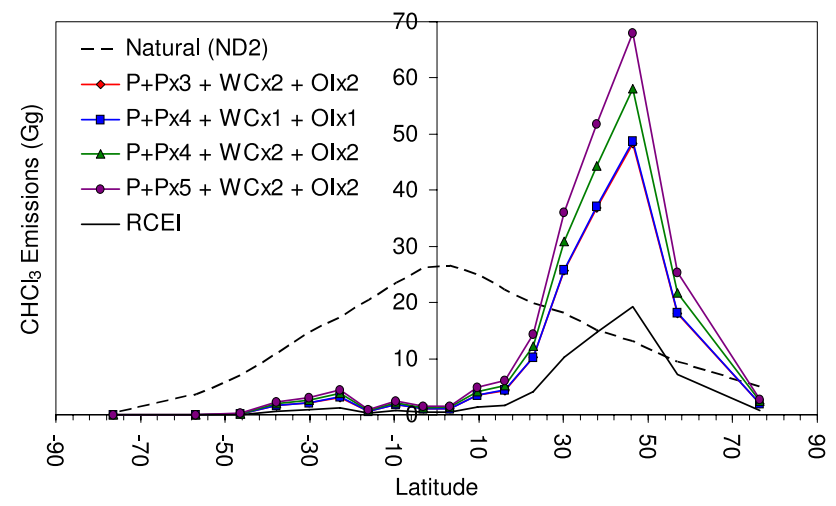

Fig. 11. A comparison of the latitudinal distribution of the increased magnitude of anthropogenic emissions (RCEI $=$ reactive chlorine emissions inventory emission figures as reported by Aucott et al. (1999); $\mathrm{P}+\mathrm{P}=$ pulp and paper; $\mathrm{WC}=$ water chlorination; $\mathrm{OI}=$ other industries) relative to the distribution of natural emissions (ND2 = natural distribution 2 as defined in Sect. 3.2.1). The x-axis represents the latitude with positive values reflecting the Northern Hemisphere and negative values the Southern Hemisphere.

the total emissions constant. The result is four different latitudinal distributions shown in Fig. 12. The base case scenario used to test these latitudinal distributions was with constant natural emissions, double the reported WC and OI emissions (Aucott et al., 1999) and four times the reported P+P emissions (Aucott et al., 1999). As might be expected the location of the maximum peak in the anthropogenic distribution has less effect on the modelled trends at sites that are far removed from the northern mid latitudes, i.e., DML and Dome C. At NGRIP (Fig. 13) the dependency is the largest and the concentrations vary by $\leq+7.6 /-7.1 \%$ between peak emissions in box 2 and boxes 1 and 4, respectively. This approach also simulates a difference in transport rates, e.g., moving the maximum peak north simulates a more northerly bias in the transport, and vice versa, that perhaps is not captured as a result of the parameterisation of the transport scheme within the 2-D model.

It is likely that the anthropogenic distribution used in this work is reasonably accurate since, for the majority of the anthropogenic emissions, the RCEI used the reported addresses of $\mathrm{CHCl}_{3}$ emitting facilities to create their grided inventory. The largest uncertainty associated with the conversion of the RCEI grided inventory into the 2-D model is from the pulp and paper emissions from China and Russia. The location of their pulp and paper plants are not known accurately since they are not listed in the International Phillips' $1997 \mathrm{~Pa}-$ per Directory (Miller Freeman Information Services 1996), which was used by Aucott et al. (1999) to locate facilities in other parts of the world. Instead, the emissions for China and Russia were re-distributed based on population density (Aucott et al., 1999). In the case of China, this issue is complicated because its geographical location straddles two of 


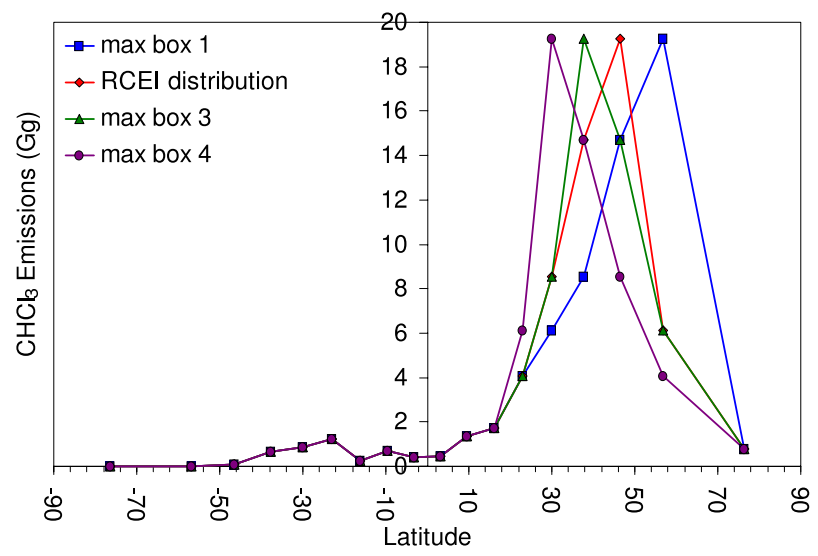

Fig. 12. The four various anthropogenic distributions used to demonstrate the sensitivity of the model to slight shifts in the location of the maximum emissions (RCEI = original latitudinal distribution determined from the reported (Aucott et al., 1999) grided inventory (Sect. 3.2.2); max box $1=$ maximum anthropogenic emissions in model box 1, i.e., most northerly box; $\max$ box $3=$ maximum anthropogenic emissions in model box 3 etc.). The $\mathrm{x}$-axis represents the latitude with positive values reflecting the Northern Hemisphere and negative values the Southern Hemisphere.

the model boxes. However, the effects are likely to be small as China and Russia are responsible for $<10 \%$ and $<5 \%$, respectively, of global pulp and paper production (Johnston, 1996).

The closest fitting model trends are shown for NGRIP, Dome $\mathrm{C}$ and DML in Fig. 14. There are four best fit trends that correspond to slightly different emission scenarios, as defined in the figure legends. The four scenarios shown incorporate either 4 or 5 times the reported $\mathrm{P}+\mathrm{P}$ emissions (Aucott et al., 1999), double the reported WC and OI emissions (Aucott et al., 1999) and either natural emissions of $280 \mathrm{Gg}$ or $224 \mathrm{Gg}$ (a reduction of $20 \%$ ). The reduced natural emissions where introduced to improve the fits to the Antarctic firn air data and are well within the estimated uncertainties reported by Khalil et al. (1999). The total anthropogenic emissions associated with these four scenarios are $190-230 \mathrm{Gg}$ at the peak in atmospheric $\mathrm{CHCl}_{3}$ around 1990. These anthropogenic emissions are significantly larger than the estimated $66 \mathrm{Gg} \mathrm{CHCl}_{3}$ reported by the RCEI (Aucott et al., 1999) and arise as a result of doubling the emissions from $\mathrm{WC}$ and $\mathrm{OI}$ and multiplying those from the $\mathrm{P}+\mathrm{P}$ industry by a factor of 4 or 5 . These increases were necessary in order to capture the magnitude of the variation observed within the firn air at NGRIP. Invoking more northerly transport would slightly reduce the estimated magnitude of these emissions.

This modelling strongly suggests that the reported anthropogenic emission estimates are underestimated, especially for the $\mathrm{P}+\mathrm{P}$ industry. The incorporated values for the $\mathrm{WC}$ and $\mathrm{OI}$ industries are within the described uncertainties of between a factor of 2 and 5 reported by Aucott (1997). How-

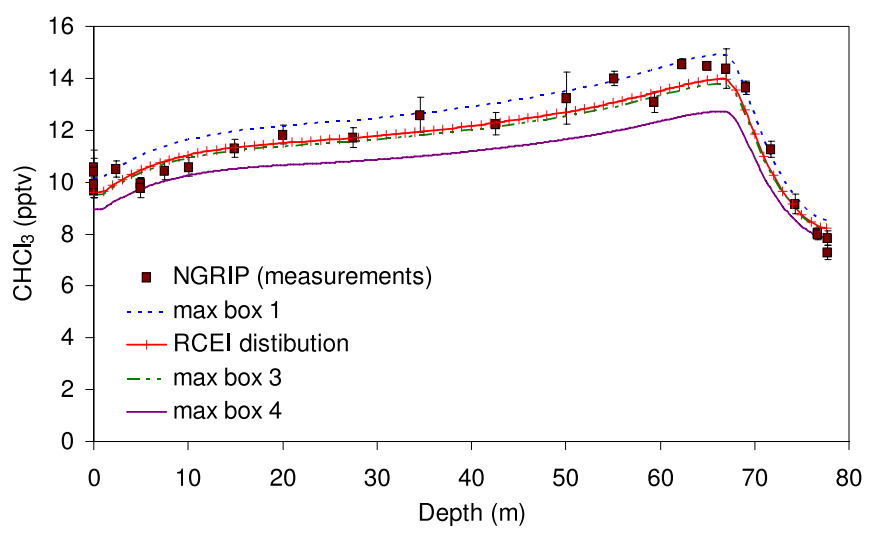

Fig. 13. A comparison of the effect on the model output at NGRIP for the four anthropogenic distributions shown in Fig. 12 (RCEI=original latitudinal distribution determined from the reported (Aucott et al., 1999) grided inventory Sect. (3.2.2); $\max$ box $1=$ maximum anthropogenic emissions in model box 1 , i.e., most northerly box; $\max$ box $3=$ maximum anthropogenic emissions in model box 3 etc.).

ever, the emission values used for the pulp and paper industry are outside the described uncertainties of a factor of 2 reported by Aucott (1997). This would suggest that the emission factors determined by Aucott (1997) to extrapolate the global emissions from the $\mathrm{P}+\mathrm{P}$ industry are likely to be underestimated and need to be re-evaluated.

At NGRIP, three of the four best fit trends model the measured maxima well. At Dome C and DML, the trends which incorporate natural emissions of $280 \mathrm{Gg}$ over predict the measurements although the general trend is well simulated (Fig. 14). However, reducing the natural emissions by $20 \%$ to $224 \mathrm{Gg}$ results in significant improvements in the model fits to the majority of the data except the shallowest firn where concentrations are slightly under estimated (Fig. 14).

\subsubsection{Varying anthropogenic emissions}

The contribution of anthropogenic sources to the total global $\mathrm{CHCl}_{3}$ emissions at the peak in 1990 was likely to have been $\sim 41-50 \%$ (Table 1) and is strongly dependent on exactly which values are chosen for the natural and anthropogenic emissions. What is clear is that this value is significantly larger than the $\sim 10-12 \%$ previously reported by Khalil et al. (1999) and McCulloch (2003) and slightly lower than the $\sim 60 \%$ estimated by Trudinger et al. (2004). This contribution declines between 1990 and 2001 as a result of the reduced emissions from the $\mathrm{P}+\mathrm{P}$ industry but is still predicted to be $\sim 25-29 \%$ in 2001 (Table 1).

The atmospheric lifetime for $\mathrm{CHCl}_{3}$ determined from the model was 0.40 .01 years, which is consistent with that recently reported by Ko et al. (2003). The total 

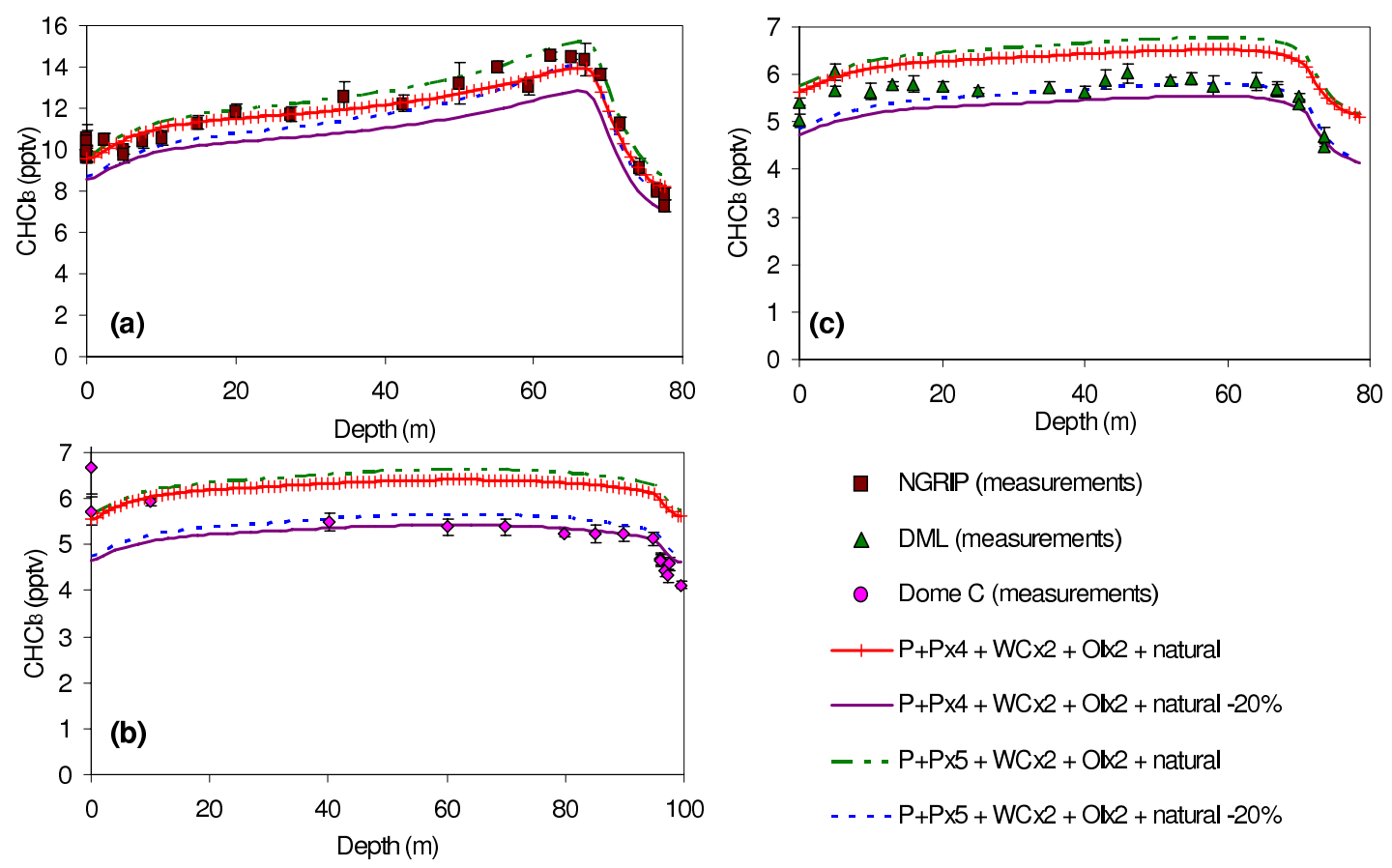

Fig. 14. A comparison of the effect of varying the magnitude of the anthropogenic $(\mathrm{P}+\mathrm{P}=$ pulp and paper; $\mathrm{WC}=$ water chlorination; $\mathrm{OI}=$ other industries) and natural sources (natural $=280 \mathrm{Gg} \mathrm{CHCl}_{3}$; natural $-20 \%=244 \mathrm{Gg} \mathrm{CHCl}_{3}$ ) on the model fit relative to the NGRIP $(\mathbf{a})$, Dome C (b) and DML (c) firn air measurements of $\mathrm{CHCl}_{3}$.

Table 1. Comparison of anthropogenic and total estimated global $\mathrm{CHCl}_{3}$ emissions from 2-D model for 1950, 1990 and 2001.

\begin{tabular}{llll}
\hline & \multicolumn{2}{c}{ Emissions Gg yr } & Anthropogenic \\
Year & Anthropogenic & Total & Contribution (\%) \\
\hline 1950 & $46-55$ & $270-335$ & $14-20$ \\
1990 & $193-226$ & $417-506$ & $41-50$ \\
2001 & $91-93$ & $315-373$ & $25-29$ \\
\hline
\end{tabular}

$\mathrm{CHCl}_{3}$ emissions associated with the best fit scenarios discussed above were $417-506 \mathrm{Gg} \mathrm{CHCl}_{3} / \mathrm{yr}$ at the maximum peak in atmospheric levels around 1990, declining to 315$373 \mathrm{Gg} \mathrm{CHCl}_{3} / \mathrm{yr}$ by 2001 , which are both within $32 \%$ of the reported modelled $\mathrm{OH}$ sink of $460 \mathrm{Gg} \mathrm{CHCl}_{3} / \mathrm{yr}$ for 1990 (Keene et al., 1999; McCulloch, 2003).

The absolute values for the global and hemispheric averages, corresponding to the scenario incorporating a $20 \%$ reduction in natural emissions and $\mathrm{P}+\mathrm{P}$ emissions 5 times those reported by Aucott et al. (1999), suggest a global background of $\sim 5.4 \mathrm{pptv}$ around the turn of the century (Fig. 15). This is higher than the $\sim 4$ pptv Southern Hemisphere background predicted by Trudinger et al. (2004), although it is important to take into account the much lower resolution of their model and that their value is more likely to be representative of southern polar latitudes. The average global concentration between 1994-1998, outputted from the 2-D
Table 2. Mean halide contents of ground and surface source waters for disinfection treatment.

\begin{tabular}{llll}
\hline $\begin{array}{l}\text { Water } \\
\text { Type }\end{array}$ & $\begin{array}{l}{\left[\mathrm{Cl}^{-}\right] / 1} \\
\mathrm{mg} / \mathrm{l}\end{array}$ & $\begin{array}{l}{\left[\mathrm{Br}^{-}\right]} \\
\mathrm{mg}\end{array}$ & References \\
\hline Ground & 25 & 0.12 & (Luong et al., 1983) \\
Surface & 35 & 0.15 & (Richardson et al., 2003) \\
Non- & - & $<2$ & \\
Seawater & & & \\
\hline
\end{tabular}

model, is 10.4 pptv, which is higher than the $8.9 \pm 0.1 \mathrm{pptv}$ reported by O'Doherty et al. (2001). The rate of decline, $0.42 \mathrm{pptv} / \mathrm{yr}$, during this period is slightly outside the errors of the estimated decrease during the same period reported by O'Doherty et al. (2001). This would suggest that there are some limitations resulting from the global extrapolation of the rapid decline in $\mathrm{CHCl}_{3}$ emissions from the USA pulp and paper industry.

\subsection{Pulp and paper production versus water chlorination}

The difference between $\mathrm{CHCl}_{3}$ and the other brominated THM modelled trends (Sect. 3.1) would suggest that the major cause of the observed variation in the $\mathrm{CHCl}_{3}$ concentrations at NGRIP does not result in significant brominated THM production. During both the processing of pulp and paper and through water chlorination, the added chlorine 


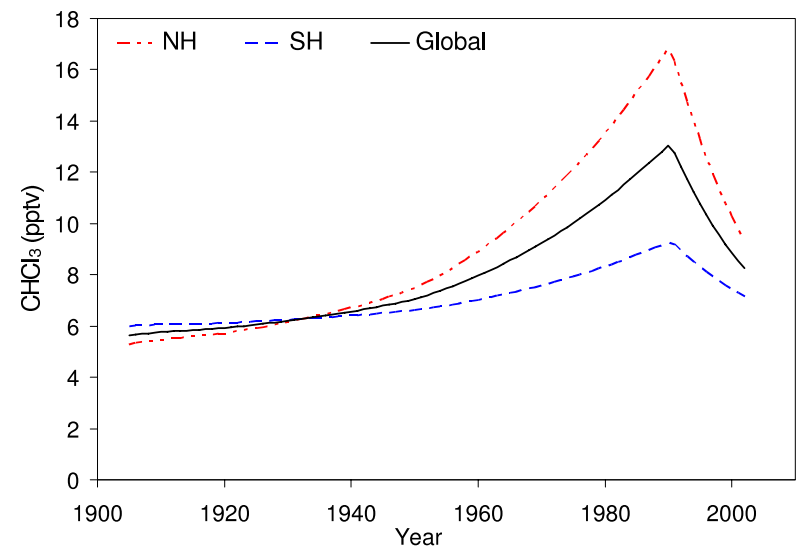

Fig. 15. The best fit modelled global and hemispheric ( $\mathrm{NH}=$ Northern Hemisphere; $\mathrm{SH}=$ Southern Hemisphere) atmospheric evolutions of $\mathrm{CHCl}_{3}$ during the 20th century.

reacts with organic material through classic haloform reactions (Ballschmiter, 2003) to form principally $\mathrm{CHCl}_{3}$, but in the presence of bromide the other brominated THM are also observed to be produced (Cooper et al., 1985; Rook, 1974; Rook et al., 1978). The major differences between these two industrial processes are the availability of bromide, which has been shown to directly effect the speciation of THM byproducts (Cooper et al., 1985; Richardson et al., 2003; Rook, 1974; Rook et al., 1978) and the amount of organic material that is present in the reaction system. It is possible to make an estimation of the available pools of organic bromine that are present during pulp and paper production and water chlorination processes. The total water chlorinated globally has been estimated to be $\sim 3.8 \times 10^{15}$ litres/yr of which $\sim 40 \%$ was inland source water, i.e., river water, and the remainder was coastal in origin, i.e., seawater (Quack and Wallace, 2003 and references therein). The reported concentrations of bromide in non-seawaters are shown in Table 2, which give a range of upper limit values for the potential formation of brominated organics assuming that all the bromide present reacts with the organic material. An estimate of the average chloride content in surface and ground waters is also shown in Table 2 for comparison. The concentration of bromide in average composition seawater has been estimated to be $67.4 \mathrm{mg} / \mathrm{l}$ (Libes, 1992). Using these figures the total organic bromine that could result from the chlorination of drinking and cooling waters is $\sim 1.5 \times 10^{14}$ grams/yr dependent on the concentration of bromide in the inland source water. In 1990, around the time of the observed maximum peak in reconstructed atmospheric $\mathrm{CHCl}_{3}$, it has been estimated that, globally, $6.27 \times 10^{10} \mathrm{~kg}$ of bleached chemical pulp was produced through the use of elemental chlorine (AET, 2001). The average bromide content of a variety of tropical and temperate woods are shown in Table 3. An estimate of the average chloride content in tropical and temperate woods is also shown in Table 3 for comparison. Using these figures the total organic bromine that could result from the production of pulp and
Table 3. Mean halide contents of tropical and temperate wood.

\begin{tabular}{lll}
\hline Wood Type & $\begin{array}{l}{\left[\mathrm{Cl}^{-}\right] \mathrm{mg} \mathrm{kg}^{-1}} \\
\text { Dry Wt. }\end{array}$ & $\begin{array}{l}{ }^{\mathrm{B}} \\
\left.\mathrm{Br}^{-}\right] \mathrm{mg} \mathrm{kg}^{-1} \\
\text { Dry Wt. }\end{array}$ \\
\hline Tropical & 254 & $3.7<10^{\mathrm{c}}$ \\
Temperate & 109 & 0.07 \\
\hline
\end{tabular}

$\mathrm{a}=$ (Watling and Harper, 1998).

$\mathrm{b}=($ Lee-Taylor and Holland, 2000).

$\mathrm{c}=($ Harper, 2005).

paper is between $4.1 \times 10^{6}-6.2 \times 10^{8}$ grams/yr, depending on whether the wood being processed is temperate or tropical in origin. These are only approximate figures and assume that all available bromide reacts with the available organic matter. However, they suggest that water chlorination has a much larger pool (6-8 orders of magnitude) of bromide and hence a greater potential to produce brominated organics, such as the brominated THM's, relative to the production of pulp and paper.

The much lower availability of bromine during the processing of pulp and paper relative to water chlorination would imply that THM by-production from this process is significantly biased towards $\mathrm{CHCl}_{3}$ formation. The difference in available bromide provides an explanation for the observed differences in the firn air measurements at NGRIP between $\mathrm{CHCl}_{3}$ and the other brominated THM species, which are most likely formed as by-products in water chlorination. Following the higher bromide concentrations in seawater it is also logical to conclude that when the source water to be chlorinated is marine derived the speciation of THM are likely to be more biased towards the bromine containing species. This suggestion is supported by larger estimates of $\mathrm{CHBr}_{3}$ production from coastal power plants relative to inland ones (Quack and Wallace, 2003) and with observations of high concentrations of $\mathrm{CHBr}_{2} \mathrm{Cl}, \mathrm{CHBrCl}_{2}$ and $\mathrm{CHBr}_{3}$ around seawater cooled power plants (Allonier et al., 1999; Jenner et al., 1997).

\subsection{Implications for the THM budgets}

Figs. 2 and 3 suggest that during the 20th century the atmospheric burdens of the brominated THM have increased. As has been described for $\mathrm{CHCl}_{3}$ (Sect. 3.1.1) the reported variations in $\mathrm{OH}$ cannot account for the observed concentration variations in the firn. It also seems unlikely that natural variations in solar radiation would have declined significantly over the last 50 years or so to account for the increases in these species considering the timescale involved.

As part of work reported by the WMO in the 2002 report the atmospheric removal rates were estimated for the brominated THM's (Table 4) by dividing the global average burden by the global average lifetime (Ko et al., 2003). The global average burden was determined by deriving an expression 
Table 4. Estimated lifetimes, removal rates/emission fluxes and associated uncertainties for the three brominated THM in the Northern Hemisphere only (Adapted from Ko et al. 2003).

\begin{tabular}{llcc}
\hline Species & $\begin{array}{l}\text { Lifetime } \\
\text { (years) }\end{array}$ & $\begin{array}{c}\text { Estimated Removal } \\
\text { Rate/Emission Flux } \\
\text { Average, [Range] }\left(\mathrm{Gg} \mathrm{Br} \mathrm{yr}^{-1}\right)\end{array}$ & $\begin{array}{c}\text { Uncertainty in Estimated } \\
\text { Removal Rate/Emission } \\
\text { Flux(\%) }\end{array}$ \\
\hline $\mathrm{CHBr}_{3}$ & 0.07 & $100,[75-125]$ & 55 \\
$\mathrm{CHBr}_{2} \mathrm{Cl}$ & 0.19 & $4.1,[2.1-6.0]$ & 66 \\
$\mathrm{CHBrCl}_{2}$ & 0.21 & $3.3,[3.1-3.5]$ & 35 \\
\hline
\end{tabular}

based on the median boundary layer mixing ratios measured during the TRACE-P, PEM tropics A and B campaigns coupled with the estimated altitudinal profiles (Ko et al., 2003). This expression assumed that removal in the stratosphere was negligible and that the atmospheric lifetime was uniform throughout the troposphere. In order to estimate the emission fluxes in the Northern Hemisphere only, the species were assumed to be in steady state such that the annual emission flux was equivalent to the annual removal rate and that value was halved. The uncertainty, shown in Table 4, reflects both the range in the estimated removal rates resulting from the different median mixing ratios and the ranges in these mixing ratios used to determine the atmospheric burdens (Ko et al., 2003). It does not include any uncertainty in the average global atmospheric lifetime.

It was possible to estimate the increase in fluxes for the three brominated THM's as a function of the observed increases from the NGRIP firn air measurements. This assumes that the concentrations at NGRIP are representative of the Northern Hemisphere such that the observed increases in the firn can be directly related to corresponding increases in the annual northern hemispheric fluxes. Between the firn close off depth and the depth $(\sim 60 \mathrm{~m})$ where the concentrations are observed to "level off" the concentrations of $\mathrm{CHBr}_{3}, \mathrm{CHBr}_{2} \mathrm{Cl}$ and $\mathrm{CHBrCl}_{2}$ are observed to increase by $16-24 \%$ (Table 5 ), which would suggest similar percentage increases in the annual fluxes reflecting the contribution from anthropogenic sources (Table 5). This depth interval in the NGRIP firn represents approximately 40 years of history $(\sim 1950-1990)$ according to dating based on the modelled and measured atmospheric evolution of CFC-12 (Sturges et al., 2001). The estimated uncertainty, shown in Table 5, reflects the combined errors from determining the observed increases in the firn between the close off depth and $60 \mathrm{~m}$ and the errors associated with the estimated removal rates.

$\mathrm{CHBr}_{3}$ has been reported to contribute $\sim 95 \%$ (Allonier et al., 1999; Jenner et al., 1997) to the total THM's measured in coastal power plant effluent such that this is reported to be the dominant source of anthropogenic $\mathrm{CHBr}_{3}$ (Quack and Wallace, 2003). As a result the contribution of the other brominated THM's $\left(\mathrm{CHBr}_{2} \mathrm{Cl}\right.$ and $\left.\mathrm{CHBrCl}_{2}\right)$ are much smaller and this difference may account for the much smaller estimated fluxes of these species relative to $\mathrm{CHBr}_{3}$ (Table 5).
Table 5. Average observed Northern Hemisphere increases in the brominated THM's from NGRIP firn air measurements, the associated uncertainties and the estimated anthropogenic fluxes based on the observed increases.

\begin{tabular}{lll}
\hline Species & $\begin{array}{l}\text { Average Observed } \\
\text { Increase (\%) }\end{array}$ & $\begin{array}{l}\text { Estimated } \\
\text { Anthropogenic } \\
\text { Flux }\left(\mathrm{Gg} \mathrm{Br} \mathrm{yr}^{-1}\right)\end{array}$ \\
\hline $\mathrm{CHBr}_{3}$ & $16 \pm 6$ & $16 \pm 8.9$ \\
$\mathrm{CHBr}_{2} \mathrm{Cl}$ & $16 \pm 5$ & $0.66 \pm 0.43$ \\
$\mathrm{CHBrCl}_{2}$ & $24 \pm 5$ & $0.79 \pm 0.28$ \\
\hline
\end{tabular}

This is in agreement with the observations of $\mathrm{CHBr}_{2} \mathrm{Cl}$ and $\mathrm{CHBrCl}_{2}$ being present at concentrations approximately 4$7 \%$ of $\mathrm{CHBr}_{3}$ in a variety of coastal power plant effluents (Allonier et al., 1999; Jenner et al., 1997). Interestingly, the estimated fluxes of $\mathrm{CHBr}_{2} \mathrm{Cl}$ and $\mathrm{CHBrCl}_{2}$ (Table 5) are 4$5 \%$ of the $\mathrm{CHBr}_{3}$ flux, which would support the source of these species being the result of seawater chlorination.

The total global emission of bromoform from both fresh and sea water chlorination has been estimated to be $\sim 28 \mathrm{Gg} \mathrm{Br} \mathrm{yr}^{-1}$ (Quack and Wallace, 2003) with the majority $(\sim 90 \%)$ being from sea water chlorination used in coastal power stations. Estimates of the hemispheric distribution of electricity production (WRI, 2004) would suggest that $>90 \%$ of these emissions $\left(\sim 25 \mathrm{Gg} \mathrm{Br} \mathrm{yr}^{-1}\right)$ are likely to be located in the Northern Hemisphere, which considering the associated uncertainties results in good agreement to the $16 \pm 8.9 \mathrm{Gg} \mathrm{Bryr}^{-1}$ estimated from this work (Table 5). However, it is important to note that our estimates are likely to be upper limits and as such our study points towards emissions that are lower than those reported by Quack and Wallace (2003). Gschwend et al. (1985) reported the total organobromines estimated to result from water chlorination to be $4.6 \mathrm{Gg} \mathrm{Bryr}^{-1}$, which was considerably lower especially considering that it also includes emissions of other bromine containing gases. The most significant difference between the estimates of Quack and Wallace (2003) and Gschwend et al. (1985) is that Quack and Wallace (2003) report that the chlorination of seawater is by far the larger source of $\mathrm{CHBr}_{3}(\sim 90 \%)$ whereas Gschwend et al. (1985) estimated that freshwater chlorination produces an order of magnitude more organobromines than seawater chlorination. 
Our results show that, in the case of bromoform at least, seawater chlorination far outweighs freshwater as an anthropogenic source of bromoform, and the small apparent atmospheric fluxes of the bromochloromethanes, which are believed to exceed emissions of bromoform in freshwater chlorination (Lepine and Archambault, 1992), also argues against a significant impact of freshwater chlorination on observed atmospheric THM concentrations.

It should be stressed that our estimated anthropogenic fluxes in Table 5 are likely to be upper limits and that these fluxes have been calculated using hemispheric average lifetimes. The emissions are likely to be mostly at mid-latitudes with transport pathways to the Arctic firn sampling sites being predominantly towards the north (Kahl et al., 1997). The relevant lifetime may, therefore, be longer than the hemispheric average lifetime. Furthermore, the observed rise in concentrations may be more representative of mid to high latitudes, particularly in the case of bromoform which is sufficiently short-lived to not be well mixed in the Northern Hemisphere. Interestingly, the absolute magnitude of $\mathrm{CHBr}_{3}$ and $\mathrm{CHBr}_{2} \mathrm{Cl}$ concentrations at NGRIP are reasonably comparable to the concentrations detected during the TRACE$\mathrm{P}$ and the PEM tropics A and B campaigns (Blake et al., 2001; Blake et al., 2003; Blake et al., 1999a; Blake et al., 1999b) that were used to determine the global burden (Ko et al., 2003).

The estimated anthropogenic fluxes for the brominated THM's suggest, assuming they are entirely the result of seawater chlorination, that seawater chlorination is a significant atmospheric source of these species accounting for $\sim 10 \%$ of the estimated global fluxes (Ko et al., 2003). However, these anthropogenic fluxes are less significant when compared to the estimated natural flux of $\sim 800 \mathrm{Gg} \mathrm{Bryr}^{-1}$ reported by Quack and Wallace (2003). Since there appears to be a measurable rise in concentrations at NGRIP this suggests that if the global flux were to be much larger than that estimated in the WMO 2002 report, then the estimated anthropogenic flux might also be proportionately larger. Conversely, if much of the global flux were located in the tropics then it might be, as a result of the shorter lifetime of $\mathrm{CHBr}_{3}$ within the tropics, that the observations at NGRIP are relatively insensitive to the magnitude of such a flux.

\section{Summary}

This work has presented polar firn air data for $\mathrm{CHCl}_{3}$ from both hemispheres that show excellent agreement between sites in the same hemisphere. We also presented evidence for changes in the $\mathrm{CHCl}_{3}$ burden over the last century, with the greatest variations occurring in the Northern Hemisphere. With the aid of 2-D atmospheric chemistry model we have shown that the contribution of anthropogenic emissions to the total global $\mathrm{CHCl}_{3}$ budget was previously been underestimated and was likely to have been as high as $\sim 50 \%$ at the maximum peak in atmospheric $\mathrm{CHCl}_{3}$ concentrations in 1990. The 2-D model results indicate that anthropogenic sources dominate over natural emissions $>20^{\circ} \mathrm{N}$ and suggest that the global $\mathrm{CHCl}_{3}$ concentration has doubled over the last century. From NGRIP firn air we have shown measurements of 5 brominated species $\left(\mathrm{CHBr}_{3}, \mathrm{CHBr}_{2} \mathrm{Cl}, \mathrm{CHBrCl}_{2}\right.$, $\mathrm{CH}_{2} \mathrm{Br}_{2}$ and $\mathrm{CH}_{2} \mathrm{BrCl}$ ) and with the aid of firn diffusion model have shown that while $\mathrm{CH}_{2} \mathrm{Br}_{2}$ is entirely of natural origin the brominated THM's show evidence for increases in their atmospheric burdens over the 20th century. These increases are suggested to be predominantly the result of the chlorination of seawater used as cooling water in coastal power stations and we estimate this source to contribute $\sim 10 \%$ to the global budgets.

Acknowledgements. This work was funded by the CEC programmes (EUK2-CT2001-00116 (CRYOSTAT) and ENV4-CT970406 (FIRETRACC)). The North GRIP project is directed and organized by the Department of Geophysics at the Niels Bohr Institute for Astronomy, Physics and Geophysics, University of Copenhagen. It is being supported by Funding Agencies in Denmark (SNF), Belgium (FNRS-CFB), France (IFRTP and INSU/CNRS), Germany (AWI), Iceland (RannIs), Japan (MEXT), Sweden (SPRS), Switzerland (SNF) and the United States of America (NSF). The fieldwork at Dome $\mathrm{C}$ was supported by the French Polar Institute (IFRTP) and of the ENEA Antarctica Project (Italy). The authors would also like to thank Claire Reeves and Kate Preston for assistance with the use of the 2-D atmospheric model.

Edited by: J. Williams

\section{References}

AET, Alliance for Environmental Technology: Trends in world chemical bleached pulp production 1990-2001, (http://www.aet. org/reports/market/2001.pdf), 2001.

Allonier, A. S., Khalanski, M., Camel, V., and Bermond, A.: Characterization of chlorination by-products in cooling effluents of coastal nuclear power stations, Mar. Pollut. Bull., 38(12), 1232 1241, 1999.

Ariya, P. A., Dastoor, A. P., Amyot, M., Schroeder, W. H., Barrie, L., Anlauf, K., Raofie, F., Ryzhkov, A., Davignon, D., Lalonde, J., and Steffen, A.: The Arctic: a sink for mercury, Tellus B, 56(5), 397-403, 2004.

Ashford, L. S., Haub, C., Kent, M. M., and Yinger, N. V.: Transitions in World Population, Population Reference Bureau, Washington D.C., USA, 2004.

Aucott, M. L.: Chlorine atoms and the global biogeochemical chlorine cycle: Estimation of the global background tropospheric concentration of chlorine atoms and discussion of key aspects of the chlorine cycle, $\mathrm{PhD}$ thesis, Rutgers University, New Brunswick, 1997.

Aucott, M. L., McCulloch, A., Graedel, T. E., Kleiman, G., Midgley, P., and Li, Y. F.: Anthropogenic emissions of trichloromethane (chloroform, $\mathrm{CHCl}_{3}$ ) and chlorodifluoromethane (HCFC-22): Reactive Chlorine Emis- 
sions Inventory, J. Geophys. Res., 104(D7), 8405-8415, 1999.

AWWA, American Water Works Association: Brief History of Drinking Water (http://www.awwa.org/advocacy/learn/info/ historyofdrinkingwater.cfm), 2004.

Ballschmiter, K.: Pattern and sources of naturally produced organohalogens in the marine environment: biogenic formation of organohalogens, Chemosphere, 52(2), 313-324, 2003.

Barrie, L. A., Bottenheim, J. W., Schnell, R. C., Crutzen, P. J., and Rasmussen, R. A.: Ozone destruction and photochemicalreactions at polar sunrise in the lower Arctic atmosphere, Nature, 334(6178), 138-141, 1988.

Berg, W. W., Heidt, L. E., Pollock, W., Sperry, P. D., Cicerone, R. J., and Gladney, E. S.: Brominated Organic-Species in the Arctic Atmosphere, Geophys. Res. Lett., 11(5), 429-432, 1984.

Blake, N. J., Blake, D. R., Simpson, I. J., Lopez, J. P., Johnston, N. A. C., Swanson, A. L., Katzenstein, A. S., Meinardi, S., Sive, B. C., Colman, J. J., Atlas, E., Flocke, F., Vay, S. A., Avery, M. A., and Rowland, F. S.: Large-scale latitudinal and vertical distributions of NMHCs and selected halocarbons in the troposphere over the Pacific Ocean during the March-April 1999 Pacific Exploratory Mission (PEM-Tropics B), J. Geophys. Res., 106(D23), 32 627-32 644, 2001.

Blake, N. J., Blake, D. R., Swanson, A. L., Atlas, E., Flocke, F., and Rowland, F. S.: Latitudinal, vertical, and seasonal variations of C-1-C-4 alkyl nitrates in the troposphere over the Pacific Ocean during PEM- Tropics A and B: Oceanic and continental sources, J. Geophys. Res., 108(D2), art. no. 8242, 2003.

Blake, N. J., Blake, D. R., Wingenter, O. W., Sive, B. C., Kang, C. H., Thornton, D. C., Bandy, A. R., Atlas, E., Flocke, F., Harris, J. M., and Rowland, F. S.: Aircraft measurements of the latitudinal, vertical, and seasonal variations of NMHCs, methyl nitrate, methyl halides, and DMS during the First Aerosol Characterization Experiment (ACE 1), J. Geophys. Res., 104(D17), 21 80321 817, 1999a.

Blake, N. J., Blake, D. R., Wingenter, O. W., Sive, B. C., McKenzie, L. M., Lopez, J. P., Simpson, I. J., Fuelberg, H. E., Sachse, G. W., Anderson, B. E., Gregory, G. L., Carroll, M. A., Albercook, G. M., and Rowland, F. S.: Influence of southern hemispheric biomass burning on midtropospheric distributions of nonmethane hydrocarbons and selected halocarbons over the remote South Pacific, J. Geophys. Res., 104(D13), 16213-16232, 1999b.

Butler, J. H., Battle, M., Bender, M. L., Montzka, S. A., Clarke, A. D., Saltzman, E. S., Sucher, C. M., Severinghaus, J. P., and Elkins, J. W.: A record of atmospheric halocarbons during the twentieth century from polar firn air, Nature, 399(6738), 749$755,1999$.

Cicerone, R. J., Heidt, L. E., and Pollock,W. H.: Measurements of atmospheric methyl bromide and bromoform, J. Geophys. Res., 93(D4), 3745-3749, 1988.

Cooper, W. J., Zika, R. G., and Steinhauer, M. S.: Bromide oxidant interactions and THM formation - a literature review, J. Am. Water Work Assoc., 77(4), 116-121, 1985.

Cox, M. L., Sturrock, G. A., Fraser, P. J., Siems, S. T., Krummel, P. B., and O'Doherty, S.: Regional sources of methyl chloride, chloroform and dichloromethane identified from AGAGE observations at Cape Grim, Tasmania, 1998-2000, J. Atmos. Chem., 45(1), 79-99, 2003.
Daniel, J. S., Solomon, S., Portmann, R. W., and Garcia, R. R.: Stratospheric ozone destruction: The importance of bromine relative to chlorine, J. Geophys. Res., 104(D19), 23 871-23 880, 1999.

Dvortsov, V. L., Geller, M. A., Solomon, S., Schauffler, S. M., Atlas, E. L., and Blake, D. R.: Rethinking reactive halogen budgets in the midlatitude lower stratosphere, Geophys. Res. Lett., 26(12), 1699-1702, 1999.

Ebinghaus, R., Kock, H. H., Temme, C., Einax, J. W., Lowe, A. G., Richter, A., Burrows, J. P., and Schroeder, W. H.: Antarctic springtime depletion of atmospheric mercury, Environ. Sci. Technol., 36(6), 1238-1244, 2002.

Fabre, A., Barnola, J. M., Arnaud, L., and Chappellaz, J.: Determination of gas diffusivity in polar firn: Comparison between experimental measurements and inverse modeling, Geophys. Res. Lett., 27(4), 557-560, 2000.

FAOSTAT, Food and Agriculture Organisation of the United Nations: Online statistical service http://faostat.fao.org/, Rome, 2004.

Foster, K. L., Plastridge, R. A., Bottenheim, J. W., Shepson, P. B., Finlayson-Pitts, B. J., and Spicer, C. W.: The role of $\mathrm{Br}_{2}$ and $\mathrm{BrCl}$ in surface ozone destruction at polar sunrise, Sci., 291(5503), 471-474, 2001.

Fraser, P. J., Oram, D. E., Reeves, C. E., Penkett, S. A., and McCulloch, A.: Southern Hemispheric halon trends (1978-1998) and global halon emissions, J. Geophys. Res., 104(D13), 15985 $15999,1999$.

Fuller, E. N., Schettle, P. D., and Giddings, J. C.: A new method for prediction of binary gas phase diffusion coeffecients, Industrial and Engineering Chemistry, 58(5), 19-27, 1966.

Gross, M. G.: Oceanography: A view of the Earth, Prentice-Hall, Old Tappan, New Jersey, 1972.

Gschwend, P. M., Macfarlane, J. K., and Newman, K. A.: Volatile halogenated organic compounds released to seawater from temperate marine macroalgae, Sci., 227(4690), 1033-1035, 1985.

IUPAC: IUPAC subcommittee on gas kinetic data evaluation (http: //www.iupac-kinetic.ch.cam.ac.uk), 2002.

Jenner, H. A., Taylor, C. J. L., van Donk, M., and Khalanski, M.: Chlorination by-products in chlorinated cooling water of some European coastal power stations, Mar. Environ. Res., 43(4), 279293, 1997.

Johnston, P. A., Stringer, R. L., Santillo, D., Stephenson, A. D., Labounskaia, I. P., and McCartney, H. M. A.: Towards zero-effluent pulp and paper production: The pivotal role 15 of totally chlorine free bleaching (http://archive.greenpeace.org/ toxics/reports/tcf/tcf.html ), Greenpeace, 1996.

Kahl, J. D. W., Martinez, D. A., Kuhns, H., Davidson, C. I., Jaffrezo, J. L., and Harris, J. M.: Air mass trajectories to Summit, Greenland: A 44-year climatology and some episodic events, J. Geophys. Res., 102(C12), 26 861-26 875, 1997.

Kaspers, K. A., van de Wal, R. S. W., de Gouw, J. A., Hofstede, C. M., van den Broeke, M. R., Reijmer, C. H., van der Veen, C., Neubert, R. E. M., Meijer, H. A. J., Brenninkmeijer, C. A. M., Karlof, L., and Winther, J. G.: Seasonal cycles of nonmethane hydrocarbons and methyl chloride, as derived from firn air from Dronning Maud Land, Antarctica, J. Geophys. Res., 109(D16), art. no.-D16306, 2004.

Keene, W. C., Khalil, M. A. K., Erickson, D. J., McCulloch, A., Graedel, T. E., Lobert, J. M., Aucott, M. L., Gong, S. L., Harper, 
D. B., Kleiman, G., Midgley, P., Moore, R. M., Seuzaret, C., Sturges, W. T., Benkovitz, C. M., Koropalov, V., Barrie, L. A., and $\mathrm{Li}$, Y. F.: Composite global emissions of reactive chlorine from anthropogenic and natural sources: Reactive Chlorine Emissions Inventory, J. Geophys. Res., 104(D7), 8429-8440, 1999.

Khalil, M. A. K., Moore, R. M., Harper, D. B., Lobert, J. M., Erickson, D. J., Koropalov, V., Sturges, W. T., and Keene, W. C.: Natural emissions of chlorine-containing gases: Reactive Chlorine Emissions Inventory, J. Geophys. Res., 104(D7), 8333-8346, 1999.

Khalil, M. A. K. and Rasmussen, R. A.: The exchange of methyl chloride and chloroform between the atmosphere and soils, Report 05-98, Department of Physics, Portland State University, Portland, Oreg., 1998.

Khalil, M. A. K. and Rasmussen, R. A.: Atmospheric chloroform, Atmos. Environ., 33(7), 1151-1158, 1999.

Khalil, M. A. K., Rasmussen, R. A., and Hoyt, S. D.: Atmospheric chloroform $\left(\mathrm{CHCl}_{3}\right)$ - Ocean air exchange and global mass balance, Tellus B, 35(4), 266-274, 1983.

Kindler, T. P., Chameides, W. L., Wine, P. H., Cunnold, D. M., Alyea, F. N., and Franklin, J. A.: The fate of atmospheric phosgene and the stratospheric chlorine loadings of its parent compounds - $\mathrm{CCl}_{4}, \mathrm{C}_{2} \mathrm{Cl}_{4}, \mathrm{C}_{2} \mathrm{HCl}_{3}, \mathrm{CH}_{3} \mathrm{CCl}_{3}$, and $\mathrm{CHCl}_{3}$, J. Geophys. Res., 100(D1), 1235-1251, 1995.

Ko, M. K. W., Poulet, G. (lead authors), Blake, D. R., Boucher, O., Burkholder, J. H., Chin, M., Cox, R. A., George, C., Graf, H.-F., Holton, J. R., Jacob, D. J., Law, K. S., Lawrence, M. G., Midgley, P. M., Seakins, P. W., Shallcross, D. E., Strahan, S. E., Wuebbles, D. J., and Yokouchi, Y.: Very short lived halogen and sulfur substances, Chapter 2, in Scientific Assessment of Ozone Depletion: 2002, Global Ozone Research and Monitoring Project, World Meteorological Organization, Geneva, Switzerland, 2003.

Kourtidis, K., Borchers, R., and Fabian, P.: Dibromomethane $\left(\mathrm{CH}_{2} \mathrm{Br}_{2}\right)$ measurements at the upper troposphere and lower stratosphere, Geophys. Res. Lett., 23(19), 2581-2583, 1996.

Krol, M. C., Lelieveld, J., Oram, D. E., Sturrock, G. A., Penkett, S. A., Brenninkmeijer, C. A. M., Gros, V., Williams, J., and Scheeren, H. A.: Continuing emissions of methyl chloroform from Europe, Nature, 421(6919), 131-135, 2003.

Lee-Taylor, J. M. and Holland, E. A.: Litter decomposition as a potential natural source of methyl bromide, J. Geophys. Res., 105(D7), 8857-8864, 2000.

Lepine, L. and Archambault, J. F.: Parts per trillion determination of trihalomethanes in water by purge and trap gas chromatography with electron capture detection, Anal. Chem., 64(7), 810-814, 1992.

Libes, S. M.: Chapter 3, Seasalt is more than $\mathrm{NaCl}$, in: An introduction to marine biogeochemistry, 30, John Wiley \& Sons Inc., New York, U.S., 1992.

Lindberg, S. E., Brooks, S., Lin, C. J., Scott, K. J., Landis, M. S., Stevens, R. K., Goodsite, M., and Richter, A.: Dynamic oxidation of gaseous mercury in the Arctic troposphere at polar sunrise, Environ. Sci. Technol., 36(6), 1245-1256, 2002.

Lobert, J. M., Keene, W. C., Logan, J. A., and Yevich, R.: Global chlorine emissions from biomass burning: Reactive Chlorine Emissions Inventory, J. Geophys. Res., 104(D7), 8373-8389, 1999.

Luong, T. V., Peters, C. J., and Perry, R.: Occurrence of bromide in source and treated waters, Effluent \& Water Treatment Journal, 23(5), 192-198, 1983.

McCulloch, A.: Chloroform in the environment: occurrence, sources, sinks and effects, Chemosphere, 50(10), 1291-1308, 2003.

Montzka, S. A., Butler, J. H., Hall, B. D., Mondeel, D. J., and Elkins, J. W.: A decline in tropospheric organic bromine, Geophys. Res. Lett., 30(15), art. no.-1826, 2003.

Muthuramu, K., Shepson, P. B., Bottenheim, J. W., Jobson, B. T., Niki, H., and Anlauf, K. G.: Relationships between Organic Nitrates and Surface Ozone Destruction During Polar Sunrise Experiment 1992, J. Geophys. Res., 99(D12), 25 369-25 378, 1994.

Nielsen, J. E. and Douglass, A. R.: Simulation of bromoform's contribution to stratospheric bromine, J. Geophys. Res., 106(D8), 8089-8100, 2001.

O’Doherty, S., Simmonds, P. G., Cunnold, D. M., Wang, H. J., Sturrock, G. A., Fraser, P. J., Ryall, D., Derwent, R. G., Weiss, R. F., Salameh, P., Miller, B. R., and Prinn, R. G.: In situ chloroform measurements at Advanced Global Atmospheric Gases Experiment atmospheric research stations from 1994 to 1998, J. Geophys. Res., 106(D17), 20 429-20 444, 2001.

Oram, D. E., Reeves, C. E., Penkett, S. A., and Fraser, P. J.: Measurements of HCFC-142b and HCFC-141b in the Cape-Grim Air Archive - 1978-1993, Geophys. Res. Lett., 22(20), 2741-2744, 1995.

Paperloop: PARS\#23 (http://www.paperloop.com), 2004.

Pfeilsticker, K., Sturges, W. T., Bosch, H., Camy-Peyret, C., Chipperfield, M. P., Engel, A., Fitzenberger, R., Muller, M., Payan, S., and Sinnhuber, B. M.: Lower stratospheric organic and inorganic bromine budget for the Arctic winter 1998/99, Geophys. Res. Lett., 27(20), 3305-3308, 2000.

Platt, U. and Honninger, G.: The role of halogen species in the troposphere, Chemosphere, 52(2), 325-338, 2003.

Prinn, R. G., Huang, J., Weiss, R. F., Cunnold, D. M., Fraser, P. J., Simmonds, P. G., McCulloch, A., Harth, C., Salameh, P., O’Doherty, S., Wang, R. H. J., Porter, L., and Miller, B. R.: Evidence for substantial variations of atmospheric hydroxyl radicals in the past two decades, Sci., 292(5523), 1882-1888, 2001.

Quack, B. and Wallace, D. W. R.: Air-sea flux of bromoform: Controls, rates, and implications, Glob. Biogeochem. Cycle, 17(1), art. no.-1023, 2003.

Reeves, C. E.: Atmospheric budget implications of the temporal and spatial trends in methyl bromide concentration, J. Geophys. Res., 108(D11), art. no.-4343, 2003.

Reeves, C. E., Sturges, W. T., Sturrock, G. A., Preston, K., Oram, D. E., Schwander, J., Mulvaney, R., Barnola, J. M., and Chappellaz, J.: Trends of halon gases in polar firn air: implications for their emission distributions, Atmos. Chem. Phys., 5, 2055-2064, 2005 , http://www.atmos-chem-phys.net/5/2055/2005/.

Richardson, S. D., Thruston, A. D., Rav-Acha, C., Groisman, L., Popilevsky, I., Juraev, O., Glezer, V., McKague, A. B., Plewa, M. J., and Wagner, E. D.: Tribromopyrrole, brominated acids, and other disinfection byproducts produced by disinfection of drinking water rich in bromide, Environ. Sci. Technol., 37(17), 3782-3793, 2003.

Robins, N. and Roberts, S.: Rethinking Paper Consumption (A discussion paper commissioned by the Ministry of Environment, Norway as part of the Organisation for Economic Co- 
operation and Development's work programme on sustainable production and consumption), International Institute for Environment and Development (IIED), http://www.poptel.org.uk/iied/ smg/pubs/rethink1.html, 1996.

Rommelaere, V., Arnaud, L., and Barnola, J. M.: Reconstructing recent atmospheric trace gas concentrations from polar firn and bubbly ice data by inverse methods, J. Geophys. Res., 102(D25), 30 069-30 083, 1997.

Rook, J. J.: Formation of haloforms during chlorination of natural waters, Water Treatment Exam, 23(2), 234-243, 1974.

Rook, J. J., Gras, A. A., Vanderheijden, B. G., and Wee, J. D.: Bromide oxidation and organic substitution in water treatment, J. Environ. Sci., Health Part A-Environ. Sci. Eng., Toxic Hazard. Subst. Control, 13(2), 91-116, 1978.

Salawitch, R. J., Weisenstein, D. K., Kovalenko, L. J., Sioris, C. E.,Wennberg, P. O., Chance, K., Ko, M. K. W., and McLinden, C. A.: Sensitivity of ozone to bromine in the lower stratosphere, Geophys. Res. Lett., 32(5), art. no.-L05811, 2005.

Sander, R., Keene, W. C., Pszenny, A. A. P., Arimoto, R., Ayers, G. P., Baboukas, E., Cainey, J. M., Crutzen, P. J., Duce, R. A., Honninger, G., Huebert, B. J., Maenhaut, W., Mihalopoulos, N., Turekian, V. C., and Van Dingenen, R.: Inorganic bromine in the marine boundary layer: a critical review, Atmos. Chem. Phys., 3, 1301-1336, 2003, http://www.atmos-chem-phys.net/3/1301/2003/.

Schauffler, S. M., Atlas, E. L., Blake, D. R., Flocke, F., Lueb, R. A., Lee-Taylor, J. M., Stroud, V., and Travnicek, W.: Distributions of brominated organic compounds in the troposphere and lower stratosphere, J. Geophys. Res., 104(D17), 21 513-21 535, 1999.

Schauffler, S. M., Atlas, E. L., Flocke, F., Lueb, R. A., Stroud, V., and Travnicek, W.: Measurements of bromine containing organic compounds at the tropical tropopause, Geophys. Res. Lett., 25(3), 317-320, 1998.

Schauffler, S. M., Heidt, L. E., Pollock, W. H., Gilpin, T. M., Vedder, J. F., Solomon, S., Lueb, R. A., and Atlas, E. L.: Measurements of halogenated organic compounds near the tropical tropopause, Geophys. Res. Lett., 20(22), 2567-2570, 1993.

Schroeder, W. H., Anlauf, K. G., Barrie, L. A., Lu, J. Y., Steffen, A., Schneeberger, D. R., and Berg, T.: Arctic springtime depletion of mercury, Nature, 394(6691), 331-332, 1998.

Schwander, J., Barnola, J. M., Andrie, C., Leuenberger, M., Ludin, A., Raynaud, D., and Stauffer, B.: The Age of the Air in the Firn and the Ice at Summit, Greenland, J. Geophys. Res., 98(D2), 2831-2838, 1993.
Sturges, W. T., McIntyre, H. P., Penkett, S. A., Chappellaz, J., Barnola, J. M., Mulvaney, R., Atlas, E., and Stroud, V.: Methyl bromide, other brominated methanes, and methyl iodide in polar firn air, J. Geophys. Res., 106(D2), 1595-1606, 2001.

Sturges, W. T., Oram, D. E. Carpenter, L. J., Penkett, S. A., and Engel, A.: Bromoform as a source of stratospheric bromine, Geophys. Res. Lett., 27(14), 2081-2084, 2000.

Trudinger, C. M., Etheridge, D. M., Sturrock, G. A., Fraser, P. J., Krummel, P. B., and McCulloch, A.: Atmospheric histories of halocarbons from analysis of Antarctic firn air: Methyl bromide, methyl chloride, chloroform, and dichloromethane, J. Geophys. Res., 109(D22), art. no.-D22310, 2004.

UN: Population Division of the Department of Economic and Social Affairs of the United Nations Secretariat, World Population Prospects: The 2004 Revision and World Urbanization Prospects: The 2003 Revision, (http://esa.un.org/unpp/), United Nations, New York, 2004.

UN: United Nations Millenium Report (http://www. unmillenniumproject.org/), 2005.

Vogt, R., Sander, R., Von Glasow, R., and Crutzen, P. J.: Iodine chemistry and its role in halogen activation and ozone loss in the marine boundary layer: A model study, J. Atmos. Chem., 32(3), 375-395, 1999.

von Glasow, R., von Kuhlmann, R., Lawrence, M. G., Platt, U., and Crutzen, P. J.: Impact of reactive bromine chemistry in the troposphere, Atmos. Chem. Phys., 4, 2481-2497, 2004, SRefID: 1680-7324/acp/2004-4-2481.

Watling, R. and Harper, D. B.: Chloromethane production by woodrotting fungi and an estimate of the global flux to the atmosphere, Mycol. Res., 102, 769-787, 1998.

WRI, World Resources Institute: EarthTrends: The Environmental Information Portal,(http://www.earthtrends.wri.org), World Resources Institute, Washington D.C., 2004.

Yokouchi, Y., Barrie, L. A., Toom, D., and Akimoto, H.: The seasonal variation of selected natural and anthropogenic halocarbons in the Arctic troposphere, Atmos. Environ., 30(10-11), 1723-1727, 1996.

Yvon-Lewis, S. A. and Butler, J. H.: Effect of oceanic uptake on atmospheric lifetimes of selected trace gases, J. Geophys. Res., 107(D20), 4414, doi:10.1029/2001JD001267, 2002. 